\title{
Attitudes, knowledge, and implementation of biotechnology and agriscience by West Virginia agricultural education teachers
}

Jason E. Hughes

West Virginia University

Follow this and additional works at: https://researchrepository.wvu.edu/etd

\section{Recommended Citation}

Hughes, Jason E., "Attitudes, knowledge, and implementation of biotechnology and agriscience by West Virginia agricultural education teachers" (2001). Graduate Theses, Dissertations, and Problem Reports. 1250.

https://researchrepository.wvu.edu/etd/1250

This Thesis is protected by copyright and/or related rights. It has been brought to you by the The Research Repository @ WVU with permission from the rights-holder(s). You are free to use this Thesis in any way that is permitted by the copyright and related rights legislation that applies to your use. For other uses you must obtain permission from the rights-holder(s) directly, unless additional rights are indicated by a Creative Commons license in the record and/ or on the work itself. This Thesis has been accepted for inclusion in WVU Graduate Theses, Dissertations, and Problem Reports collection by an authorized administrator of The Research Repository @ WVU. For more information, please contact researchrepository@mail.wvu.edu. 
Attitudes, Knowledge, and Implementation of Biotechnology and Agriscience by West Virginia Agricultural Education Teachers

Jason E. Hughes

Thesis submitted to the College of Agriculture, Forestry and Consumer Sciences

at West Virginia University in partial fulfillment of the requirements

for the degree of

Master of Science in Agricultural and Environmental Education

Stacy A. Gartin, Ph.D., Co-Chair

Harry N. Boone, Ph.D., Co-Chair

Kerry S. Odell, Ph.D. Layle D. Lawrence, Ph.D. Robert A. Dailey, Ph.D.

Division of Resource Management

Morgantown, West Virginia 2001

Keywords: Biotechnology, Agricultural Science, Agricultural Education, Science 


\begin{abstract}
Attitudes, Knowledge, and Implementation of Biotechnology and Agriscience by West Virginia Agricultural Education Teachers
\end{abstract}

Jason E. Hughes

The purpose of this study was to provide information on the attitudes toward and knowledge level of biotechnology and agriscience as well as activities conducted which demonstrate implementation of biotechnology and agriscience by West Virginia Agricultural Education teachers.

Data was collected via a questionnaire. Knowledge level, teaching methods used, attitudes of the subject and teaching responsibilities, barriers to teaching, and preferred information sources of biotechnology and agriscience were the major parts. Demographics and level of science knowledge were other parts of the questionnaire.

A major finding of the study was that West Virginia agricultural education teachers possess a positive attitude towards biotechnology, but lack some of the resources and knowledge to incorporate the subject matter into their curriculum. The teachers possess a positive attitude about agriscience, but feel that agriscience classes should not be the only classes taught in an agricultural education program. 


\section{DEDICATION}

To Mom, Dad, and Grandma Hughes, thank you for always believing in me and for instilling in me a strong work ethic. I love you.

To my four wonderful babies, Lakyn, Logan, Michaela, and Lane, you have shown me that life is not just about me. I love you.

To my lovely and talented wife, Carrie, thank you for always standing behind me and supporting me even when it was not easy. I will always love you.

iii. 


\section{ACKNOWLEDGMENTS}

Thank you JESUS for always having my best interest in mind. Your timing is always just right!

I would like to express my appreciation to all of the agriculture education teachers who participated in the survey. Without their participation, the study could not have been successfully completed.

To Dr. Gartin, thank you for being a great advisor and most of all, a friend. You have always looked out for me, and for that, I am grateful. To Dr. Boone, your efficiency amazes me. Thank you for your assistance on crunching the numbers and caring about this thesis and for me. To Dr. Lawrence, thank you for your time and wisdom. To Dr. Odell, thank you for being there for me throughout my years of education. Dr. Daily, thank you for agreeing to be on my committee and helping all teachers throughout the year.

To Don Stephens, Keith Burdette, Don Michael, and Ron Grimes, you are men who I consider having a major impact on my life's choice to be a teacher. Thank you for being great teachers. 


\section{TABLE OF CONTENTS}

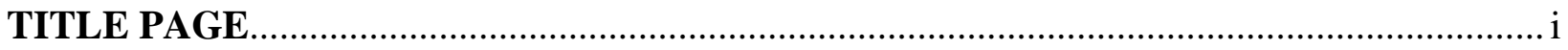

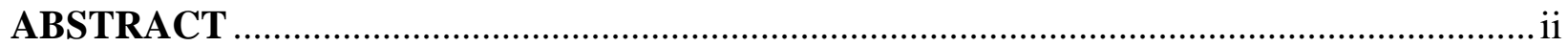

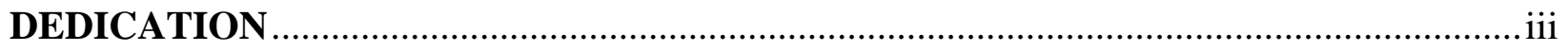

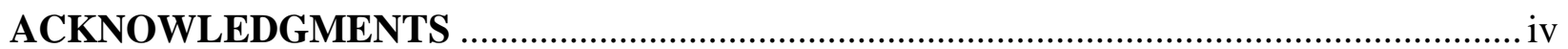

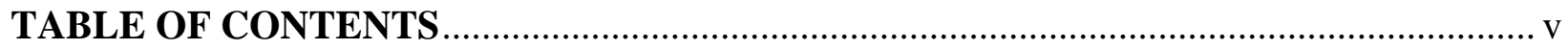

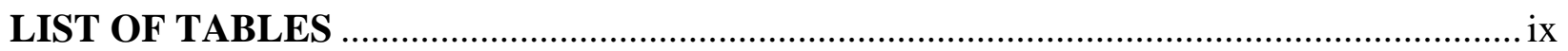

CHAPTER I

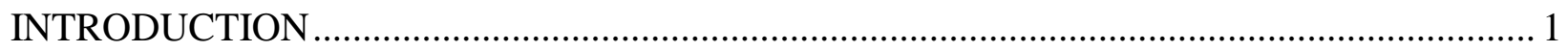

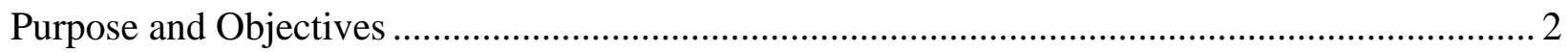

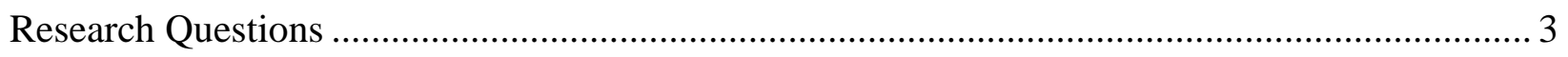

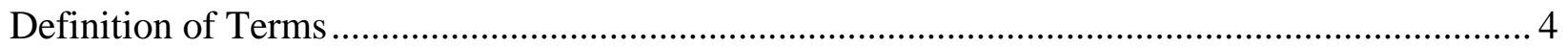

Limitations of the Study ................................................................................................... 4

CHAPTER II

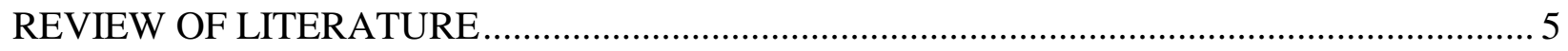

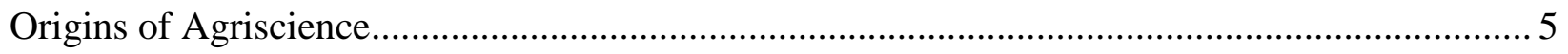

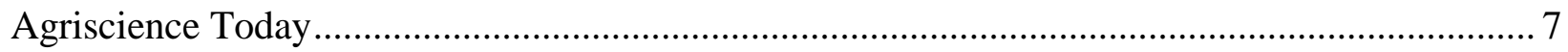

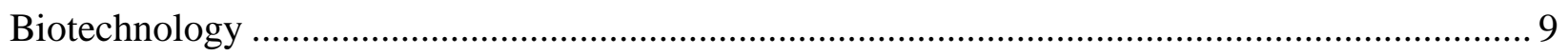

\section{CHAPTER III}

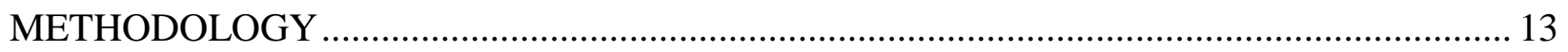

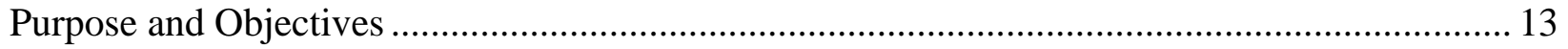




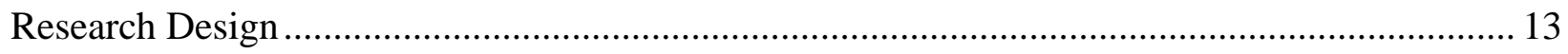

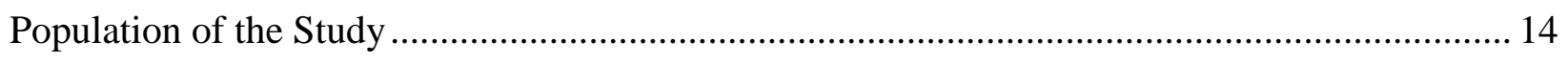

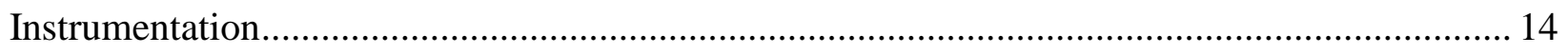

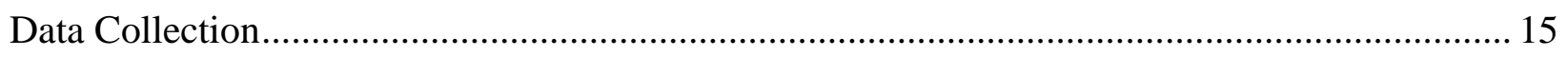

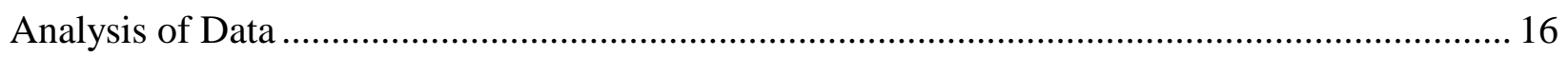

\section{CHAPTER IV}

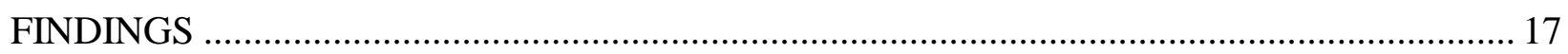

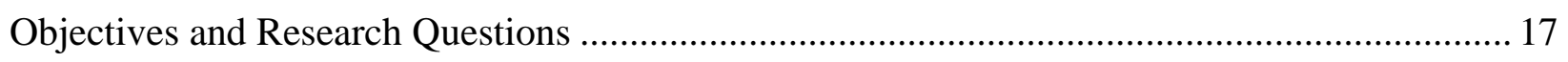

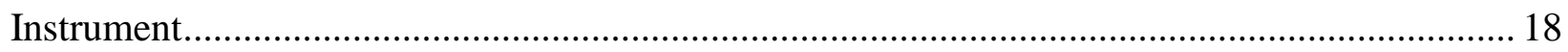

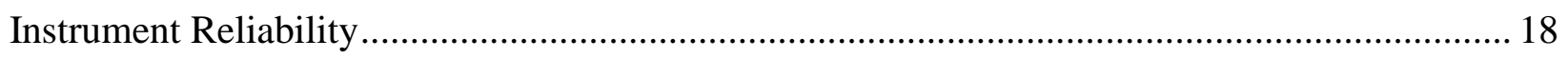

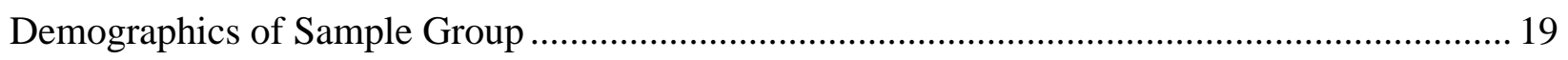

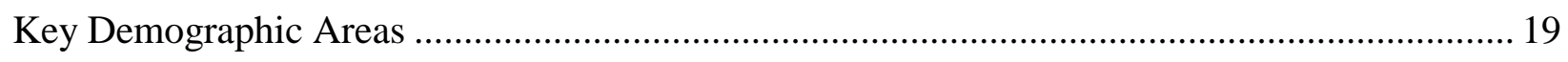

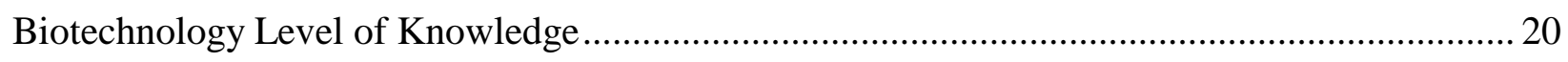

Biotechnology Teaching Methods Used ………………........................................................ 22

Relationships Between Key Demographic Areas and Biotechnology Knowledge ........................ 24

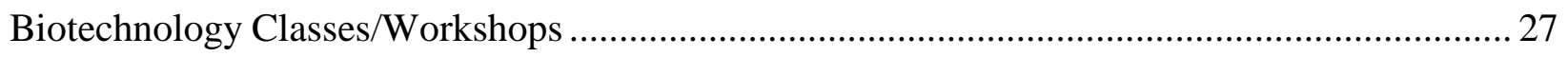

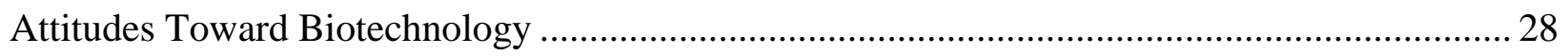

Relationships Between Key Demographic Areas and Biotechnology Attitudes..............................30

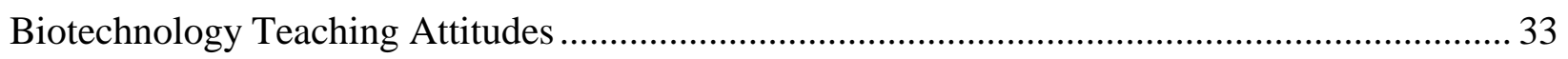

Relationships Between Key Demographic Areas and Biotechnology Teaching Attitudes ............36

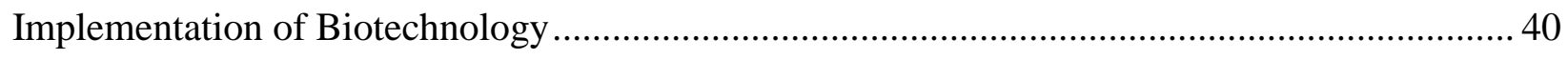


Relationships Between Key Demographic Areas and Biotechnology Barriers

Relationships Between Key Demographic Areas and Biotechnology Information Sources ......... 46

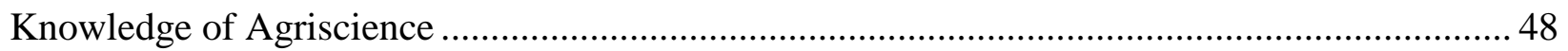

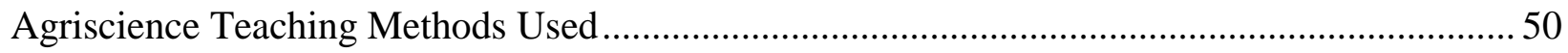

Relationships Between Key Demographic Areas and Agriscience Level of Knowledge ............ 52

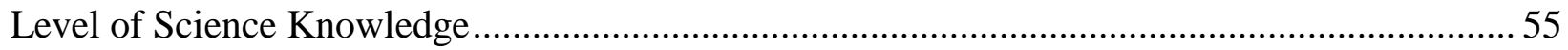

Relationships Between Key Demographic Areas and Science Level of Knowledge...................56

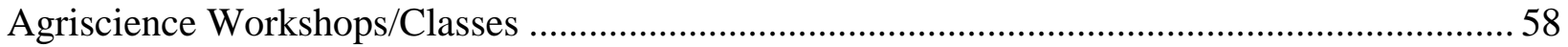

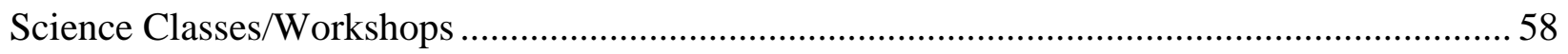

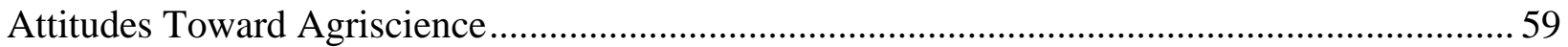

Relationships Between Key Demographic Areas and Agriscience Attitudes ........................... 62

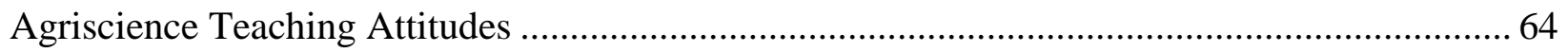

Relationships Between Key Demographic Areas and Agriscience Teaching Attitudes .............. 67

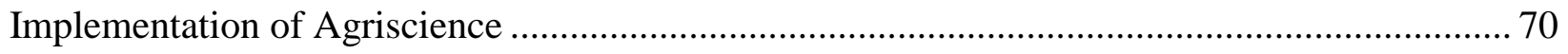

Relationships Between Key Demographic Areas and Agriscience Barriers ............................. 71

Implementation of Agriscience - Receiving Information ............................................... 74

Relationships Between Key Demographic Areas and Receiving Agriscience Information..........76

\section{CHAPTER V}

SUMMARY, CONCLUSIONS, AND RECOMMENDATIONS ....................................... 78

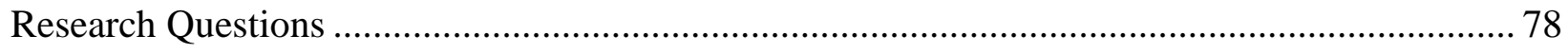

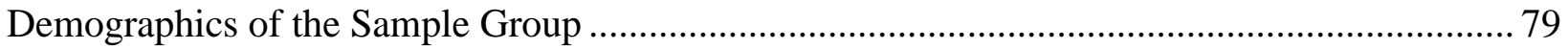

vii. 
Summary and Conclusions of Biotechnology Level of Knowledge ……................................... 80

Summary and Conclusions of Biotechnology Teaching Methods Used ....................................... 82

Summary and Conclusions of Biotechnology Classes/Workshops Attended ............................... 83

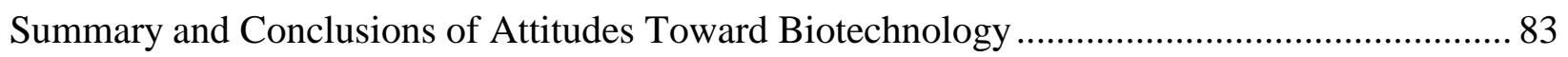

Summary and Conclusions of Implementation of Biotechnology ................................................... 85

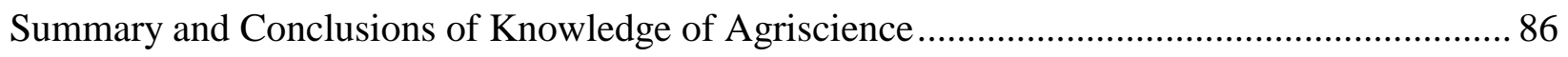

Summary and Conclusions of Agriscience Teaching Methods Used.............................................. 87

Summary and Conclusions of Agriscience Workshops/Classes Attended.................................... 88

Summary and Conclusions of Level of Science Knowledge ………............................................ 88

Summary and Conclusions of Science Classes/Workshops Attended ........................................... 89

Summary and Conclusions of Attitudes Toward Agriscience ...................................................... 90

Summary and Conclusions of Implementation of Agriscience …………………......................... 91

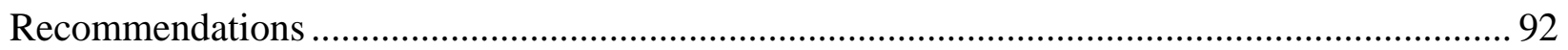

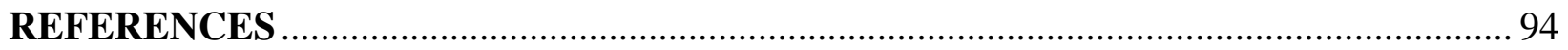

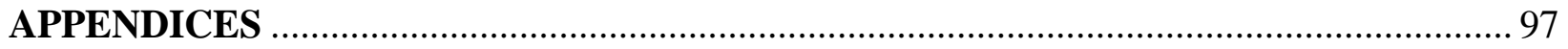

APPENDIX A: Letter to West Virginia Agricultural Education Teachers ................................... 98

APPENDIX B: Follow-up Letter to West Virginia Agricultural Education Teachers................ 100

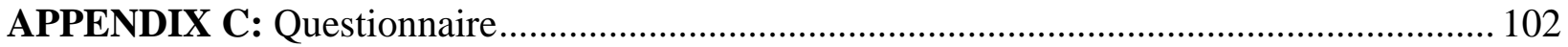

VITA

viii. 


\section{LIST OF TABLES}

1. Key Demographic Areas (Years of Teaching) .................................................................. 19

2. Key Demographic Areas (Owning a farm, owning an agribusiness, highest degree held......... 19

3. Mean and Standard Deviations of Biotechnology Level of Knowledge ............................... 20

4. Frequencies of Biotechnology Level of Knowledge ....................................................... 21

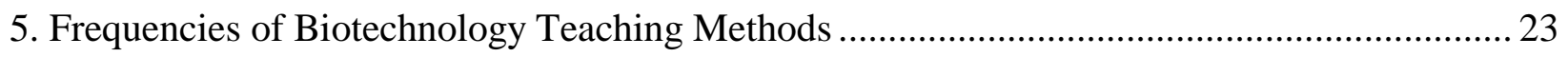

6. Relationships Between Key Demographic Areas and Biotechnology Knowledge .................. 27

7. Mean and Standard Deviations of Attitudes Toward Biotechnology ................................... 28

8. Frequencies of Attitudes Toward Biotechnology ......................................................... 29

9. Relationships Between Key Demographic Areas and Attitudes Toward Biotechnology ......... 32

10. Mean and Standard Deviations of Biotechnology Teaching Attitudes ................................ 33

11. Frequencies of Biotechnology Teaching Attitudes ..................................................... 35

12. Relationships Between Key Demographic Areas and Biotechnology Teaching Attitudes ..... 39

13. Mean and Standard Deviations of Biotechnology Barriers ............................................. 40

14. Frequencies of Biotechnology Barriers .................................................................. 41

15. Relationships Between Key Demographic Areas and Biotechnology Barriers..................... 42

16. Mean and Standard Deviations of Biotechnology Information ....................................... 45

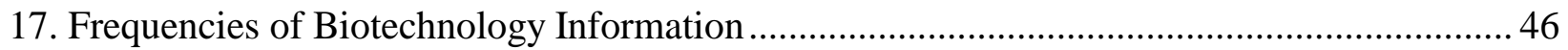

18. Relationships Between Key Demographic Areas and Biotechnology Information Sources ... 46

19. Mean and Standard Deviations of Agriscience Level of Knowledge .................................. 49

20. Frequencies of Agriscience Level of Knowledge ..........................................................50

21. Frequencies of Agriscience Teaching Methods ….......................................................... 51 
22. Relationships Between Key Demographic Areas and Agriscience Level of Knowledge ....... 54

23. Mean and Standard Deviations of Science Level of Knowledge ......................................55

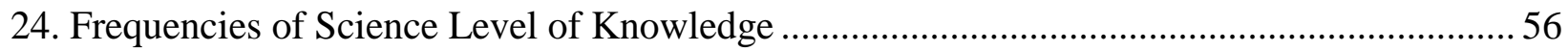

25. Relationships Between Key Demographic Areas and Science Level of Knowledge............. 58

26. Mean and Standard Deviations of Attitudes Toward Agriscience ..................................... 59

27. Frequencies of Attitudes Toward Agriscience ........................................................... 61

28. Relationships Between Key Demographic Areas and Agriscience Attitudes ....................... 63

29. Mean and Standard Deviations of Agriscience Teaching Attitudes................................... 64

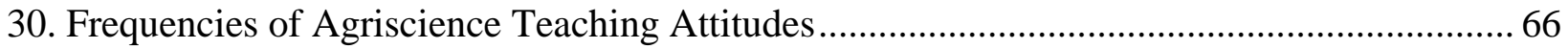

31. Relationships Between Key Demographic Areas and Agriscience Teaching Attitudes ......... 69

32. Mean and Standard Deviations of Agriscience Barriers …........................................... 70

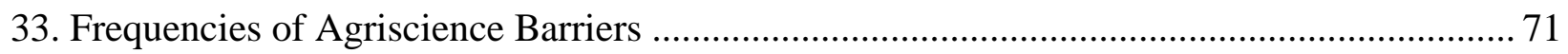

34. Relationships Between Key Demographic Areas and Agriscience Barriers ........................ 73

35. Mean and Standard Deviations of Agriscience Information .......................................... 74

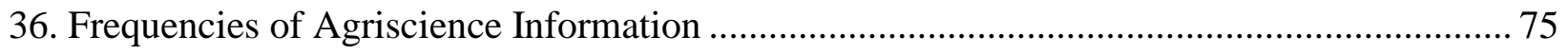

37. Relationships Between Key Demographic Areas and Receiving Agriscience Information.... 77 


\section{CHAPTER I}

\section{INTRODUCTION}

Science related competencies have always been a part of the agricultural education curriculum. Concepts and principles of chemistry, biology, genetics, physiology, and zoology are readily applied to plant and animal studies (Moss, 1985). Martin (1989) stated that, " Although sciences pertinent to agriculture are being taught, we do not know to what extent they are being taught nor do we know what is being taught and what more should be taught related to the sciences of agriculture" (p. 244).

Agriscience, bioscience, and ag-technology are all buzzwords currently being used to reflect infusion of biotechnology and genetic engineering into the agricultural education curriculum. Biotechnology involves the biology and chemistry of living organisms at the cellular level. Genetic engineering involves the transferring of genes from one organism to another. Both are having major impacts on the agricultural industry and the consumers of agriculture in this nation (National Council on Vocational Education, 1990).

According to the National Council on Vocational Education, the concern for integrating more science and technology into the agricultural curriculum has been spurred by four movements: a) the national back-to-basics emphasis on math and science; b) the national study on agricultural education in the United States which indicated that "the subject matter about agriculture and in agriculture must be broadened," this said by the National Research Council; c) the expressed need by industry for employees to be able to solve problems and think more 
critically, and d) the rapid pace by which agriculture is changing as a result of technological advances (Kirby, 1990, p. 71). Smith as cited by Martin (1989) raised the following point:

Many educators question what needs to be taught in the sciences related to agriculture. How much science should be taught in vocational agriculture programs? Is biotechnology likely to have an impact that would warrant a specialized curriculum effort? Should information on biotechnology be integrated into all aspects of the agriculture curricula? (p. 244)

Agricultural educators in West Virginia are faced with the challenge of teaching about developing technologies in agriculture. The need for more science electives being offered at the high school level has created the need for a versatile agricultural educator with strong preparation in, and knowledge of, science and agriculture. So that West Virginia agricultural educators will be prepared to deliver a more in-depth science curriculum to their students, it is important to assess the attitudes of West Virginia agricultural teachers, knowledge, and strategies for using agriculture as a means to convey these important science concepts and techniques.

\section{$\underline{\text { Purpose and Objectives }}$}

The purpose of the study was to provide information to the state supervisor of agricultural education and teacher educators that may be useful in modifying undergraduate course requirements and in planning in-service workshops and graduate courses to enhance teacher knowledge.

The primary objective of this study was to describe the attitudes of West Virginia agricultural education teachers toward and knowledge level of biotechnology and agriscience as well as activities that demonstrate implementation of biotechnology and agriscience. A secondary 
objective was to determine if there were relationships between selected demographic teacher variables and agriscience attitudes and knowledge levels.

\section{$\underline{\text { Research Questions }}$}

The following questions provided direction for the study:

1. What are the attitudes of West Virginia agricultural education teachers toward biotechnology and agriscience?

2. What level of knowledge and understanding is demonstrated by West Virginia agricultural education teachers regarding biotechnology and agriscience?

3. What teaching methods do West Virginia agricultural education teachers use when teaching biotechnology and agriscience?

4. What is the perceived role of the agricultural education teacher with regard to biotechnology?

5. What barriers do agricultural education teachers face when they teach agriscience and biotechnology?

6. What relationships exist between selected teacher demographic variables and biotechnology attitudes and knowledge levels?

7. How do West Virginia Agricultural Education teachers prefer to receive biotechnology and agriscience information? 


\section{$\underline{\text { Definition of Terms }}$}

1. West Virginia agricultural education teachers - teachers holding full-time teaching positions in secondary agricultural programs in West Virginia during the 2000-2001 school year.

2. Biotechnology - general term that refers to engineering living organisms on the cellular level.

3. Agriscience - the inclusion of science concepts in agriculture.

4. Genetic engineering - changing the genetic information in a cell, resulting in a transgenic organism.

Limitations of the Study

This study was limited to West Virginia Agricultural Education teachers employed during the 2000-2001 school year. 


\section{CHAPTER II}

\section{REVIEW OF LITERATURE}

\section{Origins of Agriscience}

The Smith-Hughes Act established secondary agriculture education in the United States in 1917. The act was designed to encourage states to promote and further develop programs of vocational education which otherwise might not be adequately provided in our state systems of education. This act provided for vocational education in agriculture, trades and industries, and homemaking (Phipps, 1988).

Before the passage of the Smith-Hughes Act of 1917, there was the Hatch Act of 1887. The Hatch Act gave American agriculture true experimentation and scientific research. There is a direct cause and effect line that can be drawn from the Hatch Act funded research findings and the establishment of the cooperative extension service that helped distribute such findings to the practitioner farmer. Can Hatch Act influence be found as directly with the early agricultural education movement? Was early agricultural education more scientifically based that the contemporary version? (Hillison, 1996, p. 8)

One of the significant national issues in agricultural education today is the role agriscience should play in middle school and high school curricula (National Research Council, 1988). "All students need an understanding of basic science concepts. Teaching science through agriculture would incorporate more agriculture into curricula while more effectively teaching science" (National Research Council, 1988, p. 11). 
Hillison (1996) raises a few questions about agriscience: "Just where did this idea of agriscience come from? What has been the evolutionary development of the program? Does it fit into a basic vocational program? Is agriscience really more academic than vocational (p. 8)?

According to Hillison (1996), two years after the passage of Hatch Act, Chamber's Encyclopedia had a definition of agricultural education that showed thinking similar to the Act. The definition used for the field was:

Agricultural Education, as at present understood, is a comprehensive term, including instruction in chemistry, geology, botany, zoology, mechanics embracing, in short the science as well as the practice of agriculture. However important branching off of education into this special track, it is only of late years that adequate attention has been paid to it. (p. 10)

Twenty-eight years after the Chamber's Encyclopedia definition of agricultural education, the Smith-Hughes Act had a different definition, according to Hillison (1996):

...any State shall provide in its plan for agricultural education that such education shall be that which is under public supervision or control; that the controlling purposes of such education shall be to fit for useful employment; that such education shall be of less than college grade and be designed to meet the needs of persons over fourteen years of age who have entered upon or who are preparing to enter upon the work of the farm or of the farm home. (p. 10)

"Obviously the Smith-Hughes Act shifted the definition of agricultural education from being science-based and academic-oriented to a strictly vocational definition (Hillison, 1996, p. 10). 
Over 100 years ago the Hatch Act used the words agricultural science. With the Act's emphasis on sophisticated research, agriculture became a leader in scientific research. With this kind of attention and support from the agricultural community, early agricultural education was considered an academic and scientific course of study. After the passage of the Smith-Hughes Act, agricultural education joined other vocational oriented instruction and de-emphasized academic instruction. However, the basic science base for the field of agriculture has not changed. (Hillison, 1996, p. 11, 12)

\section{Agriscience Today}

Buriak, as cited by Dormady (1993, p. 63) defined agriscience as "instruction in agriculture emphasizing the principles, concepts, and laws of science and their mathematical relationships supporting, describing, and explaining agriculture."

Ongoing efforts should be expanded and accelerated to upgrade the scientific and technical content of vocational agriculture courses. The "vocational" label should be avoided to help attract students with diverse interests, including college bound and those aspiring to professional and scientific careers in agriculture. Agricultural courses sufficiently upgraded in science content should be credited toward satisfying college entrance and high school graduation requirements for science courses in addition to the core curriculum.(National Research Council, 1988, p. 35)

Haye (1980) states, " If instruction in agriculture is to take its rightful place in curriculum, it should be regarded as a science and not as a vocational subject for students who cannot cope with the sciences (p. 20). 
According to Terry (1993), "The agriscience curriculum calls for something different. While FFA and Supervised Agricultural Experience (SAE) are essential parts of a total educational experience, they are of lesser importance and are more an opportunity to apply what is learned in the classroom/laboratory rather than the focus of the entire program" (p. 9).

There are a lot of similarities between teaching "regular" science (e.g., biology, chemistry, physics) and agriscience. Therein lies a potential problem. While we see a big difference between a program such as agricultural education and a course such as chemistry, others may not. With the trend toward semester courses in agricultural education, it is very easy for an administrator, at both the local and state level to view "regular" science courses and agriscience courses as being basically the same. Thus, it becomes logical to think that the chemistry teacher or the biology teacher, as well as the agriculture teacher can teach agriscience. Agriscience faces the potential danger of becoming absorbed within the science curriculum as a class rather than remaining a separate, distinct program (Vaughn, 1993).

Osborne (1993) states,

And clearly, we must focus on redefining the place and role of agricultural education in the secondary schools. But at the same time, it would be a drastic mistake to throw away everything from the past and start from scratch. We should continue to teach technical skills, job skills, entrepreneurship, and leadership skills. We should continue to teach how to grow plants and raise animals. We should continue to teach agricultural mechanics. But we should teach these topics better by linking the practices of agriculture with the science of how plants and animals grow; how machines work; and why plants, animals, and materials respond to treatments as they do. The result will be a stronger agriculture 
curriculum, a student who makes better management decisions in plant and animal agriculture, and a student who has a working knowledge of science. The right kind of agriscience instruction will make the agriculture program stronger, while making a unique contribution to the scientific literacy of students in the school.(p. 3)

\section{Biotechnology}

Rapidly evolving technologies have always pressured agricultural educators to keep abreast of developments and create relevant curricula. Biotechnology is no exception. Biotechnology is the procedures used to influence living things at the cellular level to produce commercial products. The techniques of biotechnology range from genetic engineering to fermentation, and they are among the most complex and widely applied innovations of our time. Biotechnology is already applied to agriculture in more ways than most of us suspect (Smith, 1989).

According to Lasley, "Biotechnology is a buzz word commonly heard in conversation today, but seldom understood beyond the realm of science. Yet biotechnology is being called agriculture's third wave, comparing it to machines replacing human labor and chemicals being introduced into agricultural production" (Martin, 1989, p. 243).

"Biotechnology with all its inherent complexities, mysteries, problems, and challenges, promises to revolutionize farming and agriculture. In addition, it is expected to become the major source of innovation for agriculture by the early $21^{\text {st }}$ century", according to Hardy as cited by (Martin, 1989, p. 243). 
According to Martin (1989),

Biosciences such as plant science, animal science, genetics, microbiology, soil science, and food science provide the foundation for the growth and development of the industry of agriculture. The application of biotechnology must be shared with students of agriculture in order to educate them regarding the occupation available in the field. The study of biosciences paves the way for thorough preparation for students by laying down a strong foundation in the principles and concepts of science over which a super structure of agricultural biotechnology can be built in the years to come.(p. 243) Martin (1989) goes on to say, There exists a perception among some agriculture instructors that vocational agriculture tudents are not very interested in learning the biosciences related to agriculture. This finding might be attributed to the fact that the instructors were concerned that too much focus on the sciences of agriculture may hurt enrollment instead of enhance enrollment in agriculture programs. (p. 246)

According to Pool (1988),

The teachers who provide instruction in production agriculture only in today's classroom are lost and have surely signed the death warrant for their programs. Today's instruction must reflect what is coming in the future, not what has been in the past. Look at the students in our programs and find out how many are actually living on a production farm. I suggest that if the only students you have in your program are those interested in production agriculture, you have already lost sight of where you need to be. The curriculum of tomorrow's program must be inviting to those students who are interested 
in all fields of agriculture, including agricultural related business. (p. 9)

4-H leaders and agriculture education teachers are already introducing biotechnology to future farmers. Through the Carl Perkins Vocational Education Act, the United States Congress appropriated funds to help vocational students learn about new technologies. New curricula will likely emphasize career awareness because biotechnology is creating many unexpected opportunities. It will also emphasize the impact of biotechnology on the international agricultural economy. Other areas of emphasis are the impact of biotechnology on the environment, energy, and resource conservation (Smith, 1989).

Smith (1989), feels that,

The need to learn about biotechnology extends from high school students to legislators, and the gap between agriscience and agriculture is narrowing. Through genetic engineering, today's tobacco farm could become tomorrow's factory producing raw materials for pharmaceuticals. As a result, the education of tomorrow's agriculture worker will become more complex and more interesting. High school vocational agricultural courses could begin to hold more interest for academic students interested in biochemistry and genetics.(p. 11) 


\section{CHAPTER III \\ METHODOLOGY}

\section{$\underline{\text { Purpose and Objectives }}$}

The purpose of the study was to provide information to the state supervisor of agricultural education and teacher educators that may be useful in modifying undergraduate course requirements and in planning in-service workshops and graduate courses to enhance teacher knowledge.

The primary objective of this study was to describe West Virginia agricultural teachers' attitudes toward and knowledge level of biotechnology and agriscience as well as activities that demonstrate implementation of biotechnology and agriscience. A secondary objective was to determine if there were relationships between selected demographic teacher variables and agriscience attitudes and knowledge levels.

\section{$\underline{\text { Research Design }}$}

A descriptive survey research method was used to collect data from high school agricultural education instructors in West Virginia. "Descriptive research is not generally directed toward hypothesis testing. The aim is to describe, "what exists" with respect to variables or conditions in a situation" (Ary, 1990, p. 381). It is the aim of this research to discover "what exists" among West Virginia agricultural education teachers in the areas of biotechnology and agriscience.

"Descriptive surveys focus on determining the status of a defined population with respect to certain variables. They basically inquire into the status quo; they attempt to measure what 
exists without questioning why it exists" (Ary, 1990, p. 407). This design is appropriate for determining the knowledge level, attitudes, and implementation of the study population.

Population of the Study

The population for the study included the 95 agricultural education teachers from West Virginia during the 2000-2001 school year. The population frame was established from the 20002001 West Virginia Secondary Agriculture Teachers Directory.

$\underline{\text { Instrumentation }}$

A survey was mailed to all agricultural education instructors in the state of West Virginia. The survey was organized into three major sections. Section I focused on biotechnology and had three parts. The perceived level of knowledge and teaching methods used in biotechnology was the first part. The attitudes that teachers possess on biotechnology issues and teaching biotechnology made up the second part. The third part of this section rated the implementation of biotechnology by looking at barriers and how teachers gather information.

Section II focused on agriscience and consisted of three parts. The perceived level of knowledge and teaching methods used in agriscience and the level of knowledge that teachers possess about general science subjects made up the first first part. The attitudes that teachers possess on agriscience issues and teaching agriscience made up the second part. The third part of this section rated the implementation of agriscience looking at barriers and how teachers gather information.

Section III requested demographic information including: years of experience, highest degree held, ownership of a farm, and ownership of an agribusiness. 
The questionnaire was constructed according to recommendations by Dillman (1978) and Sudman and Bradurn (1982). These include recommendations on question ordering and the color of the paper.

An existing study and instrument conducted by Kirby (1990) in North Carolina was modified for this investigation. The revised instrument was presented to a panel of experts consisting of teacher educators at West Virginia University to establish content and face validity.

A panel of experts, consisting of agricultural education teachers serving on the West Virginia Program and Policy committee, was used to pilot test the instrument. They were administered the questionnaire and the data were used to establish the instrument's reliability. Cronbach's alpha is the most widely used and appropriate reliability tool. The reliability of the instrument was found to be .9026 .

\section{$\underline{\text { Data Collection }}$}

Dillman's suggestions for constructing survey instruments, cover letters, and follow-up strategies were implemented (1978). A survey with cover letter was mailed to each of the agricultural education teachers in West Virginia. A stamped, self-addressed envelope was

provided for return of the instrument. A follow-up letter was sent two weeks after the original to remind those who had not yet responded that their cooperation was essential.

Non-response was examined by comparing late respondents to early respondents (Smith and Miller, 1983). Late respondents have been shown to be similar to non-respondents. 


\section{Analysis of Data}

This study sought to measure the knowledge level, attitudes, and implementation of WV agricultural education teachers in the areas of biotechnology and agriscience. Data collected were analyzed using SPSS at West Virginia University. Descriptive analyses were performed on the data, which are presented in narrative and tabular form. 


\section{CHAPTER IV}

\section{FINDINGS}

The purpose of the study was to provide information to the state supervisor of agricultural education and teacher educators that may be useful in modifying undergraduate course requirements and in planning in-service workshops and graduate courses to enhance teacher knowledge. To accomplish this purpose, 95 West Virginia (WV) agricultural education teachers were surveyed. Teachers were surveyed to ascertain their knowledge, attitudes, and implementation of biotechnology and agriscience.

The primary objective of this study was to describe West Virginia agricultural education teachers' attitudes toward and knowledge level of biotechnology and agriscience as well as activities which demonstrate implementation of biotechnology and agriscience. A secondary objective was to determine relationships that exist between selected demographic teacher variables and agriscience attitudes and knowledge levels.

\section{$\underline{\text { Research Questions }}$}

The following questions provided direction for the study:

1. What are the attitudes of West Virginia agricultural education teachers toward biotechnology and agriscience?

2. What level of knowledge and understanding is demonstrated by West Virginia agricultural education teachers regarding biotechnology and agriscience?

3. What teaching methods do West Virginia Agricultural Education teachers use when teaching biotechnology and agriscience? 
4. What is the perceived role of the agricultural education teacher with regard to Biotechnology?

5. What barriers do agricultural education teachers face when they teach agriscience and biotechnology, concepts and problems?

6. What relationships exist between selected teacher demographic variables and biotechnology attitudes and knowledge levels?

7. How do West Virginia Agricultural Education teachers prefer to receive biotechnology and agriscience information?

\section{$\underline{\text { Instrument }}$}

Responses of West Virginia agricultural education teachers are summarized in the following pages. Results of the data analysis are presented in the following areas: demographics of the sample group; frequency, mean, and standard deviation of biotechnology and agriscience knowledge, teaching method used, attitudes, and implementation; frequency and percent of biotechnology and agriscience knowledge, attitudes, and implementation; and relationships between biotechnology and agriscience knowledge, attitudes, and implementation and key demographic areas.

Data obtained were analyzed at West Virginia University using the Statistical Package for Social Sciences for Windows (SPSS). Data were analyzed using frequencies, percentages, means, Kendall's tau-c coefficient and Cramer's V coefficient.

\section{Demographics of the Sample Group}

The population of this study consisted of WV agricultural education teachers employed during the 2000-2001 school year. The teachers were asked how many years they had taught, 
what was the highest degree they held, if they lived on a farm, if they owned an agribusiness, and what were the courses they were currently teaching.

\section{$\underline{\text { Instrument Reliability }}$}

An existing study and instrument conducted by Kirby (1990) in North Carolina was modified for this investigation. The revised instrument was presented to a panel of experts consisting of teacher educators at West Virginia University to establish content and face validity.

A panel of experts, consisting of agricultural education teachers serving on the West Virginia Program and Policy committee, was used to pilot test the instrument. They were administered the questionnaire and the data were used to establish the instrument's reliability. Cronbach's alpha is the most widely used and appropriate reliability tool. The reliability of the instrument was found to be .9026 .

Non-response error was examined by comparing late respondents to early respondents (Smith and Miller, 1983). Late respondents have been shown to be similar to non-respondents. No statistically significant differences between the responses of early and late respondents were found.

\section{$\underline{\text { Key Demographic Areas }}$}

Information was received from 62 teachers, as noted on Table 1 and Table 2. Of the teachers reporting, the mean for years taught was 16 . When asked what was their highest degree earned the respondents indicated that 31 (50\%) held a B.S. degree, 29 (46.8\%) held a M.S. degree, and $1(1.6 \%)$ held a Ph.D. Among the respondents, $40(64.5 \%)$ operated a farm and 14 (22.6\%) owned an agribusiness. 
Table 1

Demographic Characteristics $(\mathrm{n}=62)$

\begin{tabular}{lccc}
\hline Variable & $\underline{\mathrm{f}}$ & $\underline{\mathrm{M}}$ & $\mathrm{SD}$ \\
\hline Years Taught & 62 & 16 & 9.95 \\
\hline
\end{tabular}

Table 2

Demographic Characteristics $(\mathrm{n}=62)$

\begin{tabular}{lrr}
\hline Variable & $\underline{\mathrm{f}}$ & $\%$ \\
\hline Highest Degree & & \\
BS & 31 & 50.0 \\
MS & 29 & 46.8 \\
PhD & 1 & 1.6 \\
& & \\
Operate a Farm & & \\
Yes & 40 & 64.5 \\
No & 22 & 35.5 \\
& & \\
Operate an Agribusiness & & \\
Yes & 14 & 22.6 \\
No & 48 & 77.4 \\
\hline
\end{tabular}

Biotechnology Level of Knowledge

The level of biotechnology knowledge reported by teachers can be found in Table 3 . Animal reproduction $(\mathrm{M}=3.67)$ was the only topic area that teachers indicated that they had “applied, knowledgeable.” Eleven areas of biotechnology; growth hormones (M=3.14), hybridization $(M=3.02)$, resistant plant species $(M=3.00)$, plant tissue culture $(M=2.98)$, biotechnology ethics $(M=2.93)$, cloning $(M=2.90)$, genetic modified food $(M=2.83)$, genetic engineering ( $M=2.81)$, food biotechnology $(M=2.62)$, environmental biotechnology $(M=2.60)$, and gene splicing $(\mathrm{M}=2.57)$ had means between 2.51 and 3.50, indicating that $\mathrm{WV}$ agriculture 
education teachers had "read about, possess some knowledge" about these topics. Five biotechnology topics had means score between 1.51 and 2.50. These areas, indicating that teachers had "heard about, but had very little knowledge," were microbial biotechnology $(\mathrm{M}=2.41)$, recombinant DNA $(\mathrm{M}=2.38)$, transgenic species $(\mathrm{M}=2.16)$, and electrophoresis $(\mathrm{M}=2.05)$. Bioremediation $(\mathrm{M}=1.67)$ had a mean lower than 2.00, which indicates the WV agricultural education teachers have "no knowledge" of this topic area.

Table 3

$\underline{\text { Means and Standard Deviations for Biotechnology Knowledge }(\mathrm{n}=62)}$

\begin{tabular}{lccc}
\hline Topics & $\underline{\mathrm{f}}$ & $\underline{\mathrm{M}}$ & $\underline{\mathrm{SD}}$ \\
\hline Animal Reproduction. & 57 & 3.67 & 0.64 \\
Growth Hormones (bST, pST) & 58 & 3.14 & 0.81 \\
Hybridization & 57 & 3.02 & 0.94 \\
Resistant plant species & 58 & 3.00 & 0.77 \\
Plant Tissue Culture & 55 & 2.98 & 0.87 \\
Biotech. Ethics & 57 & 2.93 & 0.73 \\
Cloning & 60 & 2.90 & 0.68 \\
Genetically modified food & 60 & 2.83 & 0.76 \\
Genetic engineering & 59 & 2.81 & 0.71 \\
Food Biotechnology & 60 & 2.62 & 0.87 \\
Environmental Biotech. & 60 & 2.60 & 0.85 \\
Gene Splicing & 60 & 2.57 & 0.75 \\
Microbial Biotechnology & 58 & 2.41 & 0.94 \\
Recombinant DNA & 60 & 2.38 & 0.90 \\
Transgenic species & 56 & 2.16 & 0.83 \\
Human Genomics & 57 & 2.10 & 0.82 \\
Electrophoresis & 59 & 2.05 & 1.02 \\
Bioremediation & 60 & 1.67 & 0.80 \\
\hline
\end{tabular}

$1=$ No knowledge

$2=$ Heard about, but very little knowledge

$3=$ Read about, possess some knowledge

4=Applied, knowledgeable

The number and percentage of agricultural education teachers reporting the level of their knowledge in eighteen areas of biotechnology is reported in Table 4. In five areas, over 50\% of 
the teachers had "read about, possess some knowledge" of the subject. Those topic areas were:

genetic engineering, cloning, genetically modified food, environmental biotechnology, and food biotechnology. At $67.7 \%$, animal reproduction was the only topic in which more than $50 \%$ of the agriculture education teachers were "applied, knowledgeable." The majority of the agricultural education teachers reported that they had "heard about, but had very little knowledge" about most of the biotechnology areas.

Table 4

Frequencies of Biotechnology Knowledge

\begin{tabular}{|c|c|c|c|c|c|c|c|c|}
\hline \multirow[b]{2}{*}{ Topics } & \multicolumn{2}{|c|}{$\begin{array}{c}\text { No } \\
\text { Knowledge } \\
\end{array}$} & \multicolumn{2}{|c|}{$\begin{array}{c}\text { Little } \\
\text { Knowledge }\end{array}$} & \multicolumn{2}{|c|}{$\begin{array}{c}\text { Some } \\
\text { Knowledge }\end{array}$} & \multicolumn{2}{|c|}{$\begin{array}{c}\text { Knowledge- } \\
\text { able }\end{array}$} \\
\hline & $\underline{\underline{f}}$ & $\%$ & $\underline{f}$ & $\%$ & $\underline{f}$ & $\%$ & $\underline{\underline{f}}$ & $\%$ \\
\hline Recombinant DNA & 12 & 19.4 & 18 & 29.0 & 25 & 40.3 & 5 & 8.1 \\
\hline Bioremediation & 30 & 48.4 & 22 & 35.5 & 6 & 9.7 & 2 & 3.2 \\
\hline Gene Splicing & 4 & 6.5 & 23 & 37.1 & 28 & 45.2 & 5 & 8.1 \\
\hline Genetic Engineering & 2 & 3.2 & 15 & 24.2 & 34 & 54.8 & 8 & 12.9 \\
\hline Cloning & 2 & 3.2 & 11 & 17.7 & 38 & 61.3 & 9 & 14.5 \\
\hline Transgenic species & 12 & 19.4 & 26 & 41.9 & 15 & 24.2 & 3 & 4.8 \\
\hline Genetically modified food & 4 & 6.5 & 11 & 17.7 & 36 & 58.1 & 9 & 14.5 \\
\hline Electrophoresis & 22 & 35.5 & 19 & 30.6 & 11 & 17.7 & 7 & 11.3 \\
\hline Environmental Biotech. & 8 & 12.9 & 14 & 22.6 & 32 & 51.6 & 6 & 9.7 \\
\hline Food Biotechnology & 9 & 14.5 & 11 & 17.7 & 34 & 54.8 & 6 & 9.7 \\
\hline Microbial Biotechnology & 11 & 17.7 & 19 & 30.6 & 21 & 33.9 & 7 & 11.3 \\
\hline Hybridization & 5 & 8.1 & 9 & 14.5 & 23 & 37.1 & 20 & 32.3 \\
\hline Plant Tissue Culture & 4 & 6.5 & 9 & 14.5 & 26 & 41.9 & 16 & 25.8 \\
\hline Resistant plant species & 2 & 3.2 & 11 & 17.7 & 30 & 48.4 & 15 & 24.2 \\
\hline Animal Reproduction & 1 & 1.6 & 2 & 3.2 & 12 & 19.4 & 42 & 67.7 \\
\hline Growth Hormones (bST/pST) & 2 & 3.2 & 9 & 14.5 & 26 & 41.9 & 21 & 33.9 \\
\hline Human Genomics & 14 & 22.6 & 25 & 40.3 & 16 & 25.8 & 2 & 3.2 \\
\hline Biotechnology Ethics & 1 & 1.6 & 14 & 22.6 & 30 & 48.4 & 12 & 19.4 \\
\hline \multicolumn{9}{|l|}{$1=$ No knowledge } \\
\hline \multicolumn{9}{|c|}{ 2=Heard about, but very little knowledge } \\
\hline \multicolumn{9}{|c|}{$3=$ Read about, possess some knowledge } \\
\hline 4=Applied, knowledgeable & & & & & & & & \\
\hline
\end{tabular}




\section{Biotechnology Teaching Methods Used}

As indicated in Table 5, 40\% of the teachers reported that they did not teach nine of the eighteen $(50 \%)$ biotechnology topics. When topics were taught, they were taught using lecture/discussion $36 \%$ of the time. Demonstrations were used to teach the biotechnology topics only $10 \%$ of the time. It was also noted that only $10 \%$ of the time were students applying biotechnology or problem solving. 


\section{Table 5}

Frequencies of Biotechnology Teaching Methods by Respondents

\begin{tabular}{|c|c|c|c|c|c|c|c|c|c|c|}
\hline \multirow[b]{2}{*}{ Topics } & \multicolumn{2}{|c|}{ Don't Teach } & \multicolumn{2}{|c|}{ Lecture/Disc. } & \multicolumn{2}{|c|}{ Demonstration } & \multicolumn{2}{|c|}{$\begin{array}{l}\text { Student } \\
\text { Applied } \\
\end{array}$} & \multicolumn{2}{|c|}{ Problem Solving } \\
\hline & $\underline{\underline{f}}$ & $\%$ & $\underline{\mathrm{f}}$ & $\%$ & $\underline{\mathrm{f}}$ & $\%$ & $\underline{\mathrm{f}}$ & $\%$ & $\underline{f}$ & $\%$ \\
\hline Recombinant DNA & 37 & 59.7 & 20 & 32.3 & 2 & 3.2 & 3 & 4.8 & 5 & 8.1 \\
\hline Bioremediation & 54 & 87.1 & 2 & 3.2 & 2 & 3.2 & 1 & 1.6 & 1 & 1.6 \\
\hline Gene Splicing & 30 & 48.4 & 2 & 3.2 & 2 & 3.2 & 2 & 3.2 & 1 & 1.6 \\
\hline Genetic Engineering & 21 & 33.9 & 36 & 58.1 & 2 & 3.2 & 2 & 3.2 & 3 & 4.8 \\
\hline Cloning & 20 & 32.3 & 32 & 51.6 & 5 & 8.1 & 5 & 8.1 & 6 & 9.7 \\
\hline Transgenic species & 41 & 66.1 & 13 & 21.0 & 1 & 1.6 & 3 & 4.8 & 1 & 1.6 \\
\hline Genetically modified food & 22 & 35.5 & 33 & 53.2 & 2 & 3.2 & 9 & 14.5 & 2 & 3.2 \\
\hline Electrophoresis & 45 & 72.6 & 9 & 14.5 & 1 & 1.6 & 1 & 1.6 & 1 & 1.6 \\
\hline Environmental Biotech. & 27 & 43.5 & 25 & 40.3 & 3 & 4.8 & 6 & 9.7 & 9 & 14.5 \\
\hline Food Biotechnology & 26 & 41.9 & 24 & 38.7 & 8 & 12.9 & 8 & 12.9 & 5 & 8.1 \\
\hline Microbial Biotechnology & 42 & 67.7 & 17 & 27.4 & 3 & 4.8 & 3 & 4.8 & 1 & 1.6 \\
\hline Hybridization & 19 & 30.6 & 29 & 46.8 & 9 & 14.5 & 12 & 19.4 & 10 & 16.1 \\
\hline Plant Tissue Culture & 22 & 35.5 & 26 & 41.9 & 13 & 21.0 & 11 & 17.7 & 10 & 16.1 \\
\hline Resistant plant species & 21 & 33.9 & 25 & 40.3 & 9 & 14.5 & 9 & 14.5 & 10 & 16.1 \\
\hline Animal Reproduction & 9 & 14.5 & 29 & 46.8 & 16 & 25.8 & 17 & 27.4 & 20 & 32.3 \\
\hline $\begin{array}{l}\text { Growth Hormones } \\
\text { (bST/pST) }\end{array}$ & 21 & 33.9 & 28 & 45.2 & 9 & 14.5 & 10 & 16.1 & 7 & 11.3 \\
\hline Human Genomics & 45 & 72.6 & 12 & 19.4 & 3 & 04.8 & 3 & 04.8 & 2 & 03.2 \\
\hline Biotech. Ethics & 19 & 30.6 & 35 & 56.5 & 2 & 03.2 & 9 & 14.5 & 10 & 16.1 \\
\hline
\end{tabular}




\section{Relationships Between Key Demographic Areas and Biotechnology Knowledge}

The biotechnology knowledge reported by teachers was correlated with the key demographic areas. Table 6 displays the correlation between the eighteen biotechnology knowledge topics and the demographics areas of years of experience, owning a farm, owning an agribusiness and degree held.

The following scale was used to describe the magnitude of relationship between variables (Davis, 1971).

\section{Coefficient Description}

.70 or higher

.50 to .69

.30 to .49

.10 to .29

.01 to .09
Very strong association (relationship)

Substantial association

Moderate association

Low association

Negligible association

As indicated in Table 6, there was a negligible relationship (Kendall's tau-c) between years of teaching experience and thirteen of the eighteen biotechnology topics. A low relationship (Kendall's tau-c) existed between years of teaching experience and human genomics (.21), transgenic species (.20), microbial biotechnology (.18), environmental biotechnology (.16), and electrophoresis (.10). The topic of human genomics was significant at the .05 level. Thirtytwo percent of the teachers with twelve years of teaching experience or less tended to have no knowledge of the subject, while, $46 \%$ of the teachers with over twelve years of experience had at least read about human genomics and had some knowledge.

There was a negligible relationship (Cramer's V) between owning a farm and the topics 
of genetically modified food (.08) and gene splicing (.07). There existed a low relationship (Cramer's V) between eleven of the eighteen biotechnology topics and owning a farm. A moderate relationship (Cramer' V) existed between owning a farm and the topics of human genomics (.35), biotechnology ethics (.33), food biotechnology (.33), and hybridization (.30). A substantial relationship (Cramer's V) existed between owning a farm and the topic of growth hormones (.50). The topic of growth hormones was significant at the .05 level. Fifty-three percent of the agricultural education teachers that owned a farm reported that they had applied and were knowledgeable about growth hormones.

There was a low relationship (Cramer's V) between owning an agribusiness and twelve of the eighteen biotechnology topics. There was a moderate relationship (Cramer's V) between owning an agribusiness and animal reproduction (.38), transgenic species (.37), environmental biotechnology (.33), biotechnology ethics (.33), and hybridization (.31). Bioremediation and animal reproduction were significant at the .05 level. Sixty-four percent of those that did own an agribusiness had no knowledge of bioremediation. Forty-five percent of those that did not own an agribusiness had no knowledge of bioremediation. Ninety-two percent of those that did own and agribusiness had applied and were knowledgeable about animal reproduction.

There was a low relationship (Cramer's V) between highest degree held and bioremediation (.29), growth hormones (.28), animal reproduction (.27), resistant plant species (.18), and human genomics (.17). There was a moderate relationship (Cramer's V) between nine of the eighteen biotechnology topics and highest degree held. There was a substantial relationship (Cramer's V) between highest degree held and transgenic species (.57), recombinant DNA (.52), gene splicing (.52), and electrophoresis (.50).

The topics of: recombinant DNA, gene splicing and transgenic species were significant at 
the .01 level. Electrophoresis was significant at the .05 level. Forty-eight percent of the teachers that held a master's degree or PhD had some knowledge or were knowledgeable about recombinant DNA. Fifty-seven percent of teachers with a bachelor's degree had some knowledge or were knowledgeable about gene splicing. Forty-eight percent of teachers with a bachelor's degree and with a master's degree had heard about but possessed very little knowledge of transgenic species. Fifty percent of master's degree teachers had heard about electrophoresis and forty-five percent of the teachers with bachelor's degrees had no knowledge. 
Table 6

Relationships Between Key Demographic Areas and Biotechnology Knowledge

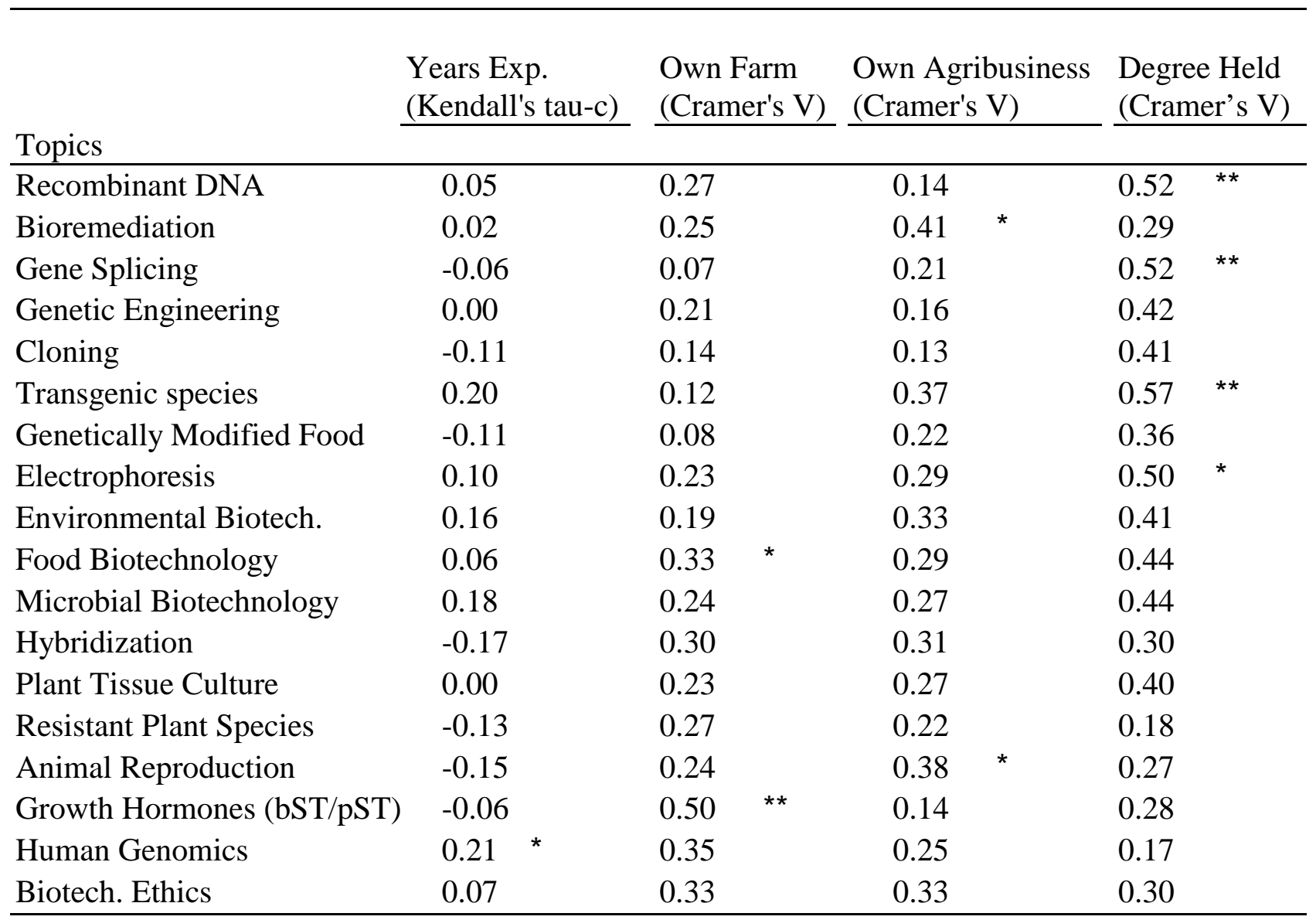

$*$ = significant at .05 level

$* *$ = significant at .01 level

Biotechnology Classes/Workshops

On average, the population of agriculture educators had attended less than one biotechnology classes/workshops (.82). Fifty-three percent of the agricultural education teachers had never taken a biotechnology class or workshop. Thirty-two percent had attended one class or workshop. Fourteen percent of the teachers had attended between two and six biotechnology classes or workshops. 


\section{Attitudes Toward Biotechnology}

Teachers were asked to express the degree of agreement or disagreement with ten attitudinal statements about biotechnology. The mean responses to those statements are reported in Table 7.

Table 7

$\underline{\text { Means and Standard Deviations for Biotechnology Attitudes (n=62) }}$

\begin{tabular}{lrrr}
\hline Topics & $\underline{\mathrm{n}}$ & $\underline{\mathrm{M}}$ & $\underline{\mathrm{SD}}$ \\
\hline Cloning living organisms is morally wrong. & 61 & 2.75 & 0.79 \\
Cross breeding to produce hybrids is morally wrong. & 62 & 3.13 & 0.97 \\
I support the use of biotechnology for human medicine. & 62 & 2.00 & 0.87 \\
I support the genetic engineering of feed crops. & 62 & 1.94 & 0.83 \\
I support the genetic engineering of food crops. & 62 & 2.03 & 0.83 \\
I support the genetic engineering of animals. & 62 & 2.19 & 0.81 \\
I support the use of biotechnology for environmental purposes. & 61 & 1.79 & 0.61 \\
Biotechnology should be a class taught by AG-ED Teachers. & 62 & 1.97 & 0.72 \\
Biotechnology should be a topic in an agriscience class. & 61 & 1.72 & 0.69 \\
I believe that local, state, and federal money should be spent & 62 & 1.79 & 0.66 \\
to enhance the teaching of biotechnology? & & & \\
\hline
\end{tabular}

$1=$ Strongly agree

2=Agree

$3=$ Disagree

4=Strongly disagree

The number and percentage of agricultural education teachers reporting their response to ten questions about biotechnology are reported in Table 8. Sixty-one percent of the teachers disagreed with the statement that cloning was morally wrong. Forty-seven percent strongly disagreed with the statement that cross breeding was morally wrong. Forty-seven percent of the teachers supported the use of genetic engineering for feed and food crops and animals. Eighty-two percent agreed and strongly agreed that agricultural education teachers should teach the topic of biotechnology. Eighty-nine percent agreed and strongly agreed that biotechnology should be a topic taught in an agriscience class. 
Table 8

Frequencies of Biotechnology Attitudes

\begin{tabular}{|c|c|c|c|c|c|c|c|c|}
\hline \multirow[b]{2}{*}{ Topics } & \multicolumn{2}{|c|}{$\begin{array}{l}\text { Strongly } \\
\text { Agree }\end{array}$} & \multicolumn{2}{|c|}{ Agree } & \multicolumn{2}{|c|}{ Disagree } & \multicolumn{2}{|c|}{$\begin{array}{l}\text { Strongly } \\
\text { Disagree }\end{array}$} \\
\hline & $\underline{f}$ & $\%$ & $\mathrm{f}$ & $\%$ & $\underline{\mathrm{f}}$ & $\%$ & $\underline{f}$ & $\%$ \\
\hline Cloning living organisms is morally wrong. & 6 & 9.7 & 10 & 16.1 & 38 & 61.3 & 7 & 11.3 \\
\hline Cross breeding to produce hybrids is morally wrong. & 4 & 6.5 & 13 & 21.0 & 16 & 25.8 & 29 & 46.8 \\
\hline I support the use of biotechnology for human medicine. & 19 & 30.6 & 28 & 45.2 & 11 & 17.7 & 4 & 6.5 \\
\hline I support the genetic engineering of feed crops. & 20 & 32.3 & 29 & 46.8 & 10 & 16.1 & 3 & 4.8 \\
\hline I support the genetic engineering of food crops. & 17 & 27.4 & 29 & 46.8 & 13 & 21.0 & 3 & 4.8 \\
\hline I support the genetic engineering of animals. & 12 & 19.4 & 29 & 46.8 & 18 & 29.0 & 3 & 4.8 \\
\hline I support the use of biotechnology for environmental purposes. & 19 & 30.6 & 36 & 58.1 & 6 & 9.7 & 1 & 1.6 \\
\hline Biotechnology should be a class taught by AG-ED Teachers. & 15 & 24.2 & 36 & 58.1 & 9 & 14.5 & 2 & 3.2 \\
\hline Biotechnology should be a topic in an agriscience class. & 24 & 38.7 & 31 & 50.0 & 5 & 8.1 & 1 & 1.6 \\
\hline $\begin{array}{l}\text { I believe that local, state, and federal money should be spent to } \\
\text { enhance the teaching of biotechnology? }\end{array}$ & 20 & 32.3 & 36 & 58.1 & 5 & 8.1 & 1 & 1.6 \\
\hline
\end{tabular}

$1=$ Strongly agree

$2=$ Agree

$3=$ Disagree

$4=$ Strongly disagree 


\section{$\underline{\text { Relationships Between Key Demographic Areas and Biotechnology Attitudes }}$}

The biotechnology attitudes reported by teachers were correlated with the key demographic variables. Table 9 displays the magnitude and significance between the responses to the ten statements about biotechnology and the demographics areas of years of experience, owning a farm, owning an agribusiness and degree held.

There was a negligible relationship (Kendall's tau-c) between years of teaching experience and six of the ten biotechnology statements. There was a low relationship (Kendall's tau-c) between years of teaching experience and the remaining four statements of: "Biotechnology should be a class taught by Ag-Ed teachers" (.24), "Biotechnology should be a topic in an agriscience class" (.14), "I support the use of biotechnology for environmental purposes" (.12), and "Cloning living organisms is morally wrong" (.11).

The statement, "Biotechnology should be a class taught by Ag-Ed teachers" was significant at the .01 level. Of the teachers that had eleven years or less of teaching experience, $96 \%$ strongly agreed or agreed that agricultural education teachers should be teaching biotechnology.

There was a negligible relationship (Cramer's V) between owning a farm and four of the six biotechnology statements. There was a low relationship (Cramer's V) between owning a farm and the following statements: "I support the use of genetic engineering for animals" (.28), "Biotechnology should be a topic in an agriscience class" (.22), "I believe that local, state, and federal money should be spent to enhance the teaching of biotechnology" (.18), and "I support the use of biotechnology for environmental purposes" (.15). A moderate relationship (Cramer's V) existed between owing a farm and the statements, "I support the use of genetic engineering of food crops" (.37) and "I support the use of genetic engineering of feed crops" (.31). The 
statement "I support the use of genetic engineering of food crops" was significant at the .05 level. Ninety-five percent of the teachers that did not own a farm supported the use of genetic engineering for food crops.

A low relationship (Cramer's V) existed between owning an agribusiness and nine of the ten biotechnology statements. A moderate relationship (Cramer's V) existed between owning an agribusiness and the statement, "Biotechnology should be a topic in an agriscience class" (.44). This same statement was significant at the .01 level. Of the teachers that owned an agribusiness, $100 \%$ strongly agreed or agreed that biotechnology should be a topic taught in an agriscience class.

A low relationship (Cramer's V) existed between highest degree held and the following biotechnology statements: "Cross breeding to produce hybrids is morally wrong" (.29), "I believe that local, state, and federal money should be spent to enhance the teaching of biotechnology" (.27), and "Biotechnology should be a topic in an agriscience class" (.26). A moderate relationship (Cramer's V) existed between highest degree held and six of the ten biotechnology statements. A substantial relationship (Cramer's V) existed between the highest degree held and the statement, "Cloning living organisms is morally wrong" (.55). This relationship was significant at the .01 level. Of the teachers that held a master's degree or higher, $89.6 \%$ did not feel that cloning was morally wrong. The relationship between highest degree and the statement, "I support the use of biotechnology for environmental purposes" was significant at the .05 level. Ninety percent of teachers that held a bachelor's degree support the use of biotechnology for environmental purposes. 
Table 9

$\underline{\text { Relationships Between Key Demographic Areas and Biotechnology Attitudes }}$

\begin{tabular}{|c|c|c|c|c|c|}
\hline Topics & $\begin{array}{l}\text { Years Exp. } \\
\text { (Kendall's tau-c) } \\
\end{array}$ & $\begin{array}{l}\text { Own Farm } \\
\text { (Cramer's V) } \\
\end{array}$ & $\begin{array}{l}\text { Own Agribusiness } \\
\text { (Cramer's V) }\end{array}$ & \multicolumn{2}{|c|}{$\begin{array}{l}\text { Degree Held } \\
(\text { Cramer's V) } \\
\end{array}$} \\
\hline Cloning living organisms is morally wrong. & 0.11 & 0.07 & 0.14 & 0.55 & $* *$ \\
\hline Cross breeding to produce hybrids is morally wrong. & 0.07 & 0.1 & 0.24 & 0.29 & \\
\hline I support the use of biotechnology for human medicine. & -0.07 & 0.06 & 0.18 & 0.3 & \\
\hline I support the genetic engineering of feed crops. & 0.01 & 0.31 & 0.15 & 0.36 & \\
\hline I support the genetic engineering of food crops. & 0.01 & 0.37 & 0.22 & 0.42 & \\
\hline I support the genetic engineering of animals. & -0.02 & 0.28 & 0.25 & 0.31 & \\
\hline I support the use of biotechnology for environmental purposes. & 0.12 & 0.15 & 0.22 & 0.42 & $*$ \\
\hline Biotechnology should be a class taught by AG-ED Teachers. & 0.24 & 0.06 & 0.17 & 0.32 & \\
\hline Biotechnology should be a topic in an agriscience class. & 0.14 & 0.22 & $0.44 * *$ & 0.26 & \\
\hline $\begin{array}{l}\text { I believe that local, state, and federal money should be spent to } \\
\text { enhance the teaching of biotechnology? }\end{array}$ & 0.06 & 0.18 & 0.29 & 0.27 & \\
\hline
\end{tabular}

$*$ = significant at .05 level

$* *$ = significant at .01 level 


\section{Biotechnology Teaching Attitudes}

Table 10 contains the mean levels for the attitudes of agricultural education teachers in the area of teaching biotechnology. Teachers were asked to respond to ten statements that all started with, "It is my job to..."

"Teach high school students about biotechnology" $(M=1.94)$ was the only statement that had a mean below 2.00 indicating that teachers agreed that it was their job to teach high school students about biotechnology. Teachers also agreed that it was their job to "educate farmers and agriculturists about biotechnology ( $\mathrm{M}=2.06)$, "involve students in biotechnology related SAEs" $(\mathrm{M}=2.11)$, "develop instructional materials and lesson plans on biotechnology" $(\mathrm{M}=2.11)$, "educate public policy makers about biotechnology" $(\mathrm{M}=2.31)$, and "educate consumers about biotechnology" (M=2.47). Teachers disagreed that it was their job to "conduct biotechnology research" $(M=2.74)$ and develop publications about biotechnology $(M=2.79)$.

Table 10

Means and Standard Deviations for Biotechnology Teaching Attitudes ( $\mathrm{n}=62$ )

\begin{tabular}{lccc}
\hline \multicolumn{1}{c}{ It is my job to... } & $\underline{\mathrm{f}}$ & $\underline{\mathrm{M}}$ & $\underline{\mathrm{SD}}$ \\
\hline develop publications about biotechnology. & 62 & 2.79 & 0.68 \\
conduct biotechnology research. & 62 & 2.74 & 0.79 \\
sponsor meetings related to biotechnology. & 62 & 2.60 & 0.66 \\
distribute publications about biotechnology. & 62 & 2.52 & 0.78 \\
educate consumers about biotechnology. & 62 & 2.47 & 0.72 \\
educate public policy makers about biotechnology & 62 & 2.31 & 0.69 \\
develop instructional materials and lesson plans on biotechnology & 62 & 2.11 & 0.55 \\
involve students in biotechnology related SAEs. & 62 & 2.11 & 0.52 \\
educate farmers and agriculturists about biotechnology & 62 & 2.06 & 0.60 \\
teach high school students about biotechnology & 62 & 1.94 & 0.57 \\
\hline 1=Strongly Agree & & & \\
2=Agree & & & \\
3=Disagree & & & \\
4=Strongly Disagree & & &
\end{tabular}


Table 11 contains the number and percentage of agricultural education teachers reporting their responses to the ten statements concerning their responsibility with biotechnology. Ninety percent strongly agreed or agreed that it was their job to teach high school students about biotechnology. Eighty-two percent strongly agreed or agreed that it was their job to educate farmers and agriculturists about biotechnology. Seventy-one percent of the teachers strongly disagreed or disagreed that it was their job to develop publications about biotechnology. Sixtytwo percent strongly disagreed or disagreed that conducting biotechnology research was their job. 
Table 11

$\underline{\text { Frequencies of Biotechnology Teaching Attitudes }}$

\begin{tabular}{|c|c|c|c|c|c|c|c|c|}
\hline \multirow[b]{2}{*}{ It is my job to... } & \multicolumn{2}{|c|}{$\begin{array}{l}\text { Strongly } \\
\text { Agree }\end{array}$} & \multicolumn{2}{|c|}{ Agree } & \multicolumn{2}{|c|}{ Disagree } & \multicolumn{2}{|c|}{$\begin{array}{l}\text { Strongly } \\
\text { Disagree }\end{array}$} \\
\hline & & $\%$ & $\underline{\mathrm{f}}$ & $\%$ & $\underline{\mathrm{f}}$ & $\%$ & $\underline{\mathrm{f}}$ & $\%$ \\
\hline teach high school students about biotechnology & 11 & 17.7 & 45 & 72.6 & 5 & 8.1 & 1 & 1.6 \\
\hline develop instructional materials and lesson plans on biotechnology. & 5 & 8.1 & 46 & 74.2 & 10 & 16.1 & 1 & 1.6 \\
\hline educate farmers and agriculturists about biotechnology. & 8 & 12.9 & 43 & 69.4 & 10 & 16.1 & 1 & 1.6 \\
\hline educate public policy makers about biotechnology. & 6 & 9.7 & 33 & 53.2 & 21 & 33.9 & 2 & 3.2 \\
\hline develop publications about biotechnology. & 2 & 3.2 & 16 & 25.8 & 37 & 59.7 & 7 & 11.3 \\
\hline educate consumers about biotechnology. & 4 & 6.5 & 29 & 46.8 & 25 & 40.3 & 4 & 6.5 \\
\hline sponsor meetings related to biotechnology. & 4 & 6.5 & 19 & 30.6 & 37 & 59.7 & 2 & 3.2 \\
\hline conduct biotechnology research. & 3 & 4.8 & 20 & 32.3 & 29 & 46.8 & 10 & 16.1 \\
\hline distribute publications about biotechnology. & 5 & 8.1 & 26 & 41.9 & 25 & 40.3 & 6 & 9.7 \\
\hline involve students in biotechnology related SAEs. & 4 & 6.5 & 48 & 77.4 & 9 & 14.5 & 1 & 1.6 \\
\hline
\end{tabular}

1=Strongly Agree

$2=$ Agree

$3=$ Disagree

4=Strongly Disagree 


\section{$\underline{\text { Relationships Between Key Demographic Areas and Biotechnology Teaching Attitudes }}$}

The attitudes towards teaching biotechnology reported by teachers were correlated with the key demographic areas. Table 12 displays the magnitude and significance between the responses to the ten statements about their job concerning biotechnology and the demographics areas of years of experience, owing a farm, owning an agribusiness and degree held.

A negligible relationship (Kendall's tau-c) existed between years of teaching experience and all ten "It is my job to..." statements.

A low relationship (Cramer's V) existed between owning a farm and seven of the ten "It is my job to..." statements. There was a moderate relationship (Cramer's V) between owning a farm and the following "It is my job to..."statements: "involve students in biotechnology related SAEs" (.32), "teach high school students about biotechnology" (.32), and "educate farmers and agriculturists about biotechnology" (.31).

A low relationship (Cramer's V) existed between owning an agribusiness and six of the ten "It is my job to..." statements. A moderate relationship (Cramer's V) existed between owning an agribusiness and the following "It is my job to..."statements: "distribute publications about biotechnology" (.44), "teach high school students about biotechnology" (.38), "sponsor meetings related to biotechnology" (.36), and "involve students in biotechnology related SAEs" (.30). The "It is my job to..." statement, "distribute publications about biotechnology" was significant at the .01 level.

Seventy-two percent of the teachers that owned an agribusiness believed that it was the job of the agricultural education teacher to distribute publications about biotechnology.

The "It is my job to..." statement "teach high school students about biotechnology" was significant at the .05 level. Of the teachers that owned an agribusiness, $100 \%$ felt that it was the 
job of the agricultural education teacher to teach biotechnology. The "It is my job to..." statement "sponsor meetings related to biotechnology" was significant at the .05 level.

A moderate relationship (Cramer's V) existed between highest degree held and the following "It is my job to..." statements: "educate public policy makers about biotechnology" (.44), "teach high school students about biotechnology" (.39), and "educate farmers and agriculturists about biotechnology" (.36). There was a substantial relationship (Cramer's V) between highest degree held and six of the ten "It is my job to..." statements. A very strong relationship (Cramer's V) existed between highest degree held and "It is my job to..." statement "develop publications about biotechnology" (.75). The following "It is my job to..." statements were significant at the .01 level: "conduct biotechnology research", "involve students in biotechnology related SAEs", "sponsor meetings related to biotechnology", and "develop publications about biotechnology." The following "It is my job to..." statements were significant at the .05 level: "develop instructional materials and lesson plant on biotechnology", "educate consumers about biotechnology," and "distribute publications about biotechnology." Sixty-nine percent of the teachers with master's degree did not feel that it was their job to conduct biotechnology research. Eighty-three percent of the teachers that held a master's degree or Ph.D. agreed it was the teacher's job to involve students in biotechnology related SAEs. Seventy percent of teachers with master's degrees did not feel that it was their job to sponsor biotechnology related meetings. Eighty-three percent of the teachers that held a master's degree did not agree that it was their job to develop biotechnology publications. Of the teachers with bachelor's degree, $87 \%$ felt that it was their job to develop instructional materials and lesson plans on biotechnology. Fifty-eight percent of the teachers that held a bachelor's degree agreed that it was the their job to educate consumers about biotechnology. Fifty percent of the teachers 
that held a master's degree or Ph.D. believed it was their job to distribute biotechnology

publications. 
Table 12

$\underline{\text { Relationships Between Key Demographic Areas and Biotechnology Teaching Attitudes }}$

\begin{tabular}{|c|c|c|c|c|c|c|}
\hline It is my job to... & $\begin{array}{l}\text { Years Exp. } \\
\text { (Kendall's tau-c) }\end{array}$ & $\begin{array}{l}\text { Own Farm } \\
(\text { Cramer's V) } \\
\end{array}$ & \multicolumn{2}{|c|}{$\begin{array}{l}\text { Own Agribusiness } \\
\text { (Cramer's V) }\end{array}$} & \multicolumn{2}{|c|}{$\begin{array}{l}\text { Degree Held } \\
(\text { Cramer's V) } \\
\end{array}$} \\
\hline teach high school students about biotechnology & -0.03 & 0.32 & 0.38 & $*$ & 0.39 & \\
\hline develop instructional materials and lesson plans on biotech. & 0.06 & 0.29 & 0.27 & & 0.51 & $*$ \\
\hline educate farmers and agriculturists about biotechnology. & -0.08 & 0.31 & 0.29 & & 0.36 & \\
\hline educate consumers about biotechnology. & -0.11 & 0.21 & 0.18 & & 0.51 & $*$ \\
\hline sponsor meetings related to biotechnology. & -0.05 & 0.26 & 0.36 & $*$ & 0.55 & $* *$ \\
\hline conduct biotechnology research. & -0.07 & 0.20 & 0.13 & & 0.59 & $* *$ \\
\hline distribute publications about biotechnology. & -0.12 & 0.25 & 0.44 & $* *$ & 0.50 & $*$ \\
\hline involve students in biotechnology related SAEs. & -0.09 & 0.32 & 0.30 & & 0.54 & $* *$ \\
\hline
\end{tabular}

$*$ = significant at the .05 level

$* *$ significant at the .01 level 


\section{Implementation of Biotechnology}

Table 13 displays the means for biotechnology teaching implementation barriers. Agricultural education teachers responded to a list of nine potential barriers to teaching biotechnology.

Equipment $(M=3.31)$ and instructional materials $(M=3.1)$ had the highest mean scores, indicating that teachers considered these to be moderate barriers to teaching biotechnology. Classroom/lab space $(M=2.98)$, time $(M=2.95)$, textbooks $(M=2.92)$, teacher knowledge $(\mathrm{M}=2.87)$, and student academic ability $(\mathrm{M}=2.66)$ were also considered moderate barriers to teaching biotechnology. Community support $(\mathrm{M}=2.00)$ and administration acceptance $(\mathrm{M}=2.00)$ had the lowest mean score indicating that teachers considered these factors to be minor barriers to teaching biotechnology.

Table 13

$\underline{\text { Means and Standard Deviations for Biotechnology Implementation Barriers }(\mathrm{n}=62)}$

\begin{tabular}{llll}
\hline Barrier & $\underline{\mathrm{f}}$ & $\underline{\mathrm{M}}$ & $\underline{\mathrm{SD}}$ \\
\hline Equipment & 62 & 3.31 & 0.78 \\
Instructional Materials & 62 & 3.10 & 0.74 \\
Classroom/Lab Space & 62 & 2.98 & 0.93 \\
Time & 62 & 2.95 & 0.93 \\
Textbooks & 62 & 2.92 & 0.98 \\
Teacher Knowledge & 61 & 2.87 & 0.81 \\
Student Academic Ability & 62 & 2.66 & 0.89 \\
Administration Acceptance & 62 & 2.00 & 0.99 \\
Community & 62 & 2.00 & 0.94 \\
\hline
\end{tabular}

$1=$ Not at all

2=Minor

$3=$ Moderate

4=Major 
The number and percentage of agricultural education teachers reporting the barriers that they confront in teaching biotechnology is presented in Table 14.

As indicated in Table 14, teachers considered equipment, instructional materials, and classroom/lab space to be their greatest barriers for teaching biotechnology. Over $72 \%$ of the teachers considered these barriers to be moderate or major. Community support and administration acceptance, were two factors that most agricultural education teachers did not view as barriers to teaching biotechnology. Only 30.7\% considered community support and $29.1 \%$ administration acceptance a moderate or major barrier.

Table 14

Frequencies of Biotechnology Implementation Barriers

\begin{tabular}{|c|c|c|c|c|c|c|c|c|}
\hline \multirow[b]{2}{*}{ Barrier } & \multicolumn{2}{|c|}{ Not at all } & \multicolumn{2}{|c|}{ Minor } & \multicolumn{2}{|c|}{ Moderate } & \multicolumn{2}{|c|}{ Major } \\
\hline & $\overline{\mathrm{f}}$ & $\%$ & $\underline{f}$ & $\%$ & $\underline{f}$ & $\%$ & $\underline{f}$ & $\%$ \\
\hline Equipment & 1 & 1.6 & 9 & 14.5 & 22 & 35.5 & 30 & 48.4 \\
\hline Instructional Materials & 2 & 3.2 & 8 & 12.9 & 34 & 54.8 & 18 & 29.0 \\
\hline Textbooks & 7 & 11.3 & 11 & 17.7 & 24 & 38.7 & 20 & 32.3 \\
\hline Student Academic Ability & 7 & 11.3 & 17 & 27.4 & 28 & 45.2 & 10 & 16.1 \\
\hline Teacher Knowledge & 2 & 3.2 & 18 & 29.0 & 27 & 43.5 & 14 & 22.6 \\
\hline Time & 6 & 9.7 & 10 & 16.1 & 27 & 43.5 & 19 & 30.6 \\
\hline Classroom/Lab Space & 5 & 8.1 & 12 & 19.4 & 24 & 38.7 & 21 & 33.9 \\
\hline Community & 23 & 37.1 & 20 & 32.3 & 15 & 24.2 & 4 & 6.5 \\
\hline Administration Acceptance & 24 & 38.7 & 20 & 32.3 & 12 & 19.4 & 6 & 9.7 \\
\hline $\begin{array}{l}1=\text { Not at all } \\
2=\text { Minor } \\
3=\text { Moderate } \\
4=\text { Major }\end{array}$ & & & & & & & & \\
\hline
\end{tabular}




\section{$\underline{\text { Relationships Between Key Demographic Areas and Biotechnology Barriers }}$}

The biotechnology teaching barriers reported by teachers were correlated with the key demographic areas. Table 15 displays the magnitude and significance between the responses to nine listed barriers to teaching biotechnology and the demographics areas of years of experience, owing a farm, owning an agribusiness and degree held.

A negligible relationship (Kendall's tau-c) existed between years of teaching experience and five of the nine biotechnology barriers. A low relationship (Kendall's tau-c) existed between years of teaching experience and the biotechnology barriers of instructional materials (.13), community (.13), and teacher knowledge (.20). A moderate relationship (Kendall's tau-c) existed between years of teaching experience and the biotechnology barrier of time (.30). The barrier of time was significant at the .01 level. Eighty-six percent of the teachers that did not own a farm reported time as a moderate or major barrier for teaching biotechnology. The biotechnology barrier of teacher knowledge was significant at the .05 level. Seventy-two percent of teachers with twelve years of experience or more reported that their knowledge of biotechnology was a moderate to major barrier to teaching biotechnology.

A negligible relationship (Cramer's V) existed between owning a farm and the biotechnology barriers of textbooks (.09) and instructional materials (.06). A low relationship (Cramer's V) existed between owning a farm and six of the nine biotechnology barriers. A moderate relationship (Cramer's V) existed between owning a farm and the barrier of time (.36).

A low relationship (Cramer's V) existed between owning an agribusiness and eight of the nine biotechnology barriers. A moderate relationship (Cramer's V) existed between owning and agribusiness and the barrier of equipment (.31).

A low relationship (Cramer's V) existed between highest degree held and the 
biotechnology barriers of student academic ability (.26), community (.23), and teacher knowledge (.19). A moderate relationship (Cramer's V) existed between six of the nine biotechnology barriers. The barrier of classroom/lab space was significant at the .05 level. A relatively similar percentage of teachers with bachelor's degrees (74.2\%) and master's degrees (72.4\%) reported that classroom/lab space was a moderate or major barrier. 
Table 15

$\underline{\text { Relationships Between Key Demographic Areas and Biotechnology Implementation Barriers }}$

\begin{tabular}{|c|c|c|c|c|}
\hline \multirow{2}{*}{ Barrier } & $\begin{array}{l}\text { Years Exp. } \\
\text { (Kendall's tau-c) }\end{array}$ & \multirow[t]{2}{*}{$\begin{array}{l}\text { Own Farm } \\
(\text { Cramer's V) } \\
\end{array}$} & \multirow[t]{2}{*}{$\begin{array}{l}\text { Own Agribusiness } \\
\text { (Cramer's V) }\end{array}$} & $\begin{array}{l}\text { Degree Held } \\
(\text { Cramer's V }\end{array}$ \\
\hline & & & & \\
\hline Equipment & -0.01 & 0.20 & 0.31 & 0.43 \\
\hline Instructional Materials & 0.13 & 0.06 & 0.17 & 0.42 \\
\hline Textbooks & 0.08 & 0.09 & 0.22 & 0.33 \\
\hline Student Academic Ability & 0.06 & 0.22 & 0.17 & 0.26 \\
\hline Teacher Knowledge & 0.21 & 0.20 & 0.19 & 0.19 \\
\hline Time & 0.30 & 0.36 & 0.23 & 0.35 \\
\hline Classroom/Lab Space & 0.00 & 0.18 & 0.14 & 0.49 \\
\hline Community & 0.13 & 0.20 & 0.23 & 0.23 \\
\hline Administration Acceptance & 0.03 & 0.19 & 0.18 & 0.32 \\
\hline
\end{tabular}

$*=$ significant at the .05 level

$* *=$ significant at the .01 level 


\section{Biotechnology Information}

Table 16 displays the preferences of agricultural education teachers regarding how they would like to receive information about biotechnology. A list of nine sources of information was given for teachers to rate.

All nine sources of agriscience information had means ranging from 1.52 to 2.16 indicating that agricultural education teachers prefer receiving biotechnology information from all nine sources. The Internet $(M=2.16)$ and slide sets/movies $(M=2.16)$ had the highest means while workshops $(\mathrm{M}=1.52)$ had the lowest mean indicating the teachers would prefer having workshops on biotechnology more than any other information source.

Table 16

Means and Standard Deviations for Biotechnology Implementation - Receiving Information (n=62)

\begin{tabular}{llll}
\hline Information Source & $\underline{\mathrm{f}}$ & $\underline{\mathrm{M}}$ & $\underline{\mathrm{SD}}$ \\
\hline Slide sets/movies & 62 & 2.16 & 0.85 \\
Internet & 62 & 2.16 & 0.73 \\
CD-Rom & 62 & 1.92 & 0.84 \\
Computer Programs & 62 & 1.85 & 0.76 \\
Textbooks & 62 & 1.85 & 0.62 \\
Video Tapes & 62 & 1.82 & 0.71 \\
University courses & 61 & 1.82 & 0.81 \\
Lesson Plans & 62 & 1.79 & 0.68 \\
Workshops & 62 & 1.52 & 0.59 \\
\hline
\end{tabular}

1=Strongly Agree

$2=$ Agree

$3=$ Disagree

4=Strongly Disagree 
The number and percent of teachers reporting the way that they would prefer to receive information about biotechnology is reported in Table 17.

All nine areas were rated desirable sources of receiving information. Twenty-nine percent of the teachers thought the Internet was not a desirable source and $32.3 \%$ felt that slide sets/movies were not desirable sources of biotechnology information.

Table 17

Frequencies of Biotechnology Implementation - Receiving Information

\begin{tabular}{|c|c|c|c|c|c|c|c|c|}
\hline \multirow[b]{2}{*}{ Information Source } & \multicolumn{2}{|c|}{ Strongly Agree } & \multicolumn{2}{|c|}{ Agree } & \multicolumn{2}{|c|}{ Disagree } & \multicolumn{2}{|c|}{ Strongly Disagree } \\
\hline & $\underline{\underline{f}}$ & $\%$ & $\underline{f}$ & $\%$ & $\underline{\mathrm{f}}$ & $\%$ & $\underline{f}$ & $\%$ \\
\hline Internet & 10 & 16.1 & 34 & 54.8 & 16 & 25.8 & 2 & 3.2 \\
\hline Workshops & 32 & 51.6 & 29 & 46.8 & 0 & 0.0 & 1 & 1.6 \\
\hline Video Tapes & 20 & 32.3 & 35 & 56.5 & 5 & 8.1 & 2 & 3.2 \\
\hline Slide sets/movies & 14 & 22.6 & 28 & 45.2 & 16 & 25.8 & 4 & 6.5 \\
\hline University courses & 23 & 37.1 & 29 & 46.8 & 6 & 9.7 & 3 & 4.8 \\
\hline Lesson Plans & 21 & 33.9 & 34 & 54.8 & 6 & 9.7 & 1 & 1.6 \\
\hline Textbooks & 16 & 25.8 & 40 & 64.5 & 5 & 8.1 & 1 & 1.6 \\
\hline Computer Programs & 22 & 35.5 & 28 & 45.2 & 11 & 17.7 & 1 & 1.6 \\
\hline CD-Rom & 21 & 33.9 & 28 & 45.2 & 10 & 16.1 & 3 & 4.8 \\
\hline
\end{tabular}

1=Strongly Agree

$2=$ Agree

3=Disagree

4=Strongly Disagree

$\underline{\text { Relationships Between Key Demographic Areas and Biotechnology Information Sources }}$

The information sources that agricultural education teachers prefer to receive information on biotechnology were correlated with the key demographic areas. Table 18 displays the magnitude and significance between the responses to nine listed information sources for biotechnology and the demographics areas of years of experience, owing a farm, owning an agribusiness and degree held. 
A negligible relationship (Kendall's tau-c) existed between years of teaching experience and six of the nine biotechnology information sources. A low relationship (Kendall's tau-c) existed between years of teaching experience and the information sources of workshops (.12) and lesson plans (.10). A very strong relationship (Kendall's tau-c) existed between years of teaching experience and the Internet (.80).

A negligible relationship (Cramer's V) existed between owning a farm and the biotechnology information source of university courses (-.07). Seven of the nine information sources had a low relationship (Cramer's V) with owning a farm. A moderate relationship (Cramer's V) existed between owning a farm and CD-Rom (.30).

A negligible relationship (Cramer's V) existed between owning an agribusiness and the biotechnology information source of workshops (.07). A low relationship (Cramer's V) existed between five of the nine information sources. A moderate relationship (Cramer's V) existed between owning an agribusiness and the information sources of CD-Rom (.39), computer programs (.33), and university courses (.33). The information source of CD-Rom was significant at the .05 level. Seventy-nine percent of the teachers that did not own an agribusiness responded that they would prefer biotechnology information on CD-ROM.

A low relationship (Cramer's V) existed between highest degree held and six of nine biotechnology information sources. A moderate relationship (Cramer's V) existed between highest degree held and the information sources of Internet (.37), slide sets/movies (.33), and lesson plans (.30). 
Table 18

Relationships Between Key Demographic Areas and Biotechnology Implementation - Receiving Information

\begin{tabular}{llllll}
\hline & $\begin{array}{l}\text { Years Exp. } \\
\text { (Kendall's tau-c) }\end{array}$ & $\begin{array}{l}\text { Own Farm } \\
\text { (Cramer's V) }\end{array}$ & & $\begin{array}{l}\text { Own Agribusiness } \\
\text { (Cramer's V) }\end{array}$ & $\begin{array}{l}\text { Degree Held } \\
\text { (Cramer's V) }\end{array}$ \\
\cline { 2 - 3 } Information Source & & & & \\
\cline { 1 - 2 } Internet & 0.80 & 0.15 & 0.13 & 0.37 \\
Workshops & 0.12 & 0.14 & 0.07 & 0.18 \\
Video Tapes & -0.11 & 0.14 & 0.15 & 0.19 \\
Slide sets/movies & 0.05 & 0.17 & 0.17 & 0.33 \\
University courses & -0.02 & 0.07 & 0.33 & 0.21 \\
Lesson Plans & 0.10 & 0.11 & 0.19 & 0.30 \\
Textbooks & -0.01 & 0.10 & 0.22 & 0.23 \\
Computer Programs & 0.04 & 0.22 & 0.33 & 0.26 \\
CD-Rom & 0.06 & 0.30 & 0.39 & 0.23 \\
\hline
\end{tabular}

$*$ = significant at the .05 level

$* *$ significant at the .01 level

Knowledge of Agriscience

The agriscience knowledge mean rating reported by teachers is located in Table 19. All twelve areas of agriscience had means above 3.00. The topics of soil science $(M=3.87)$, animal and vet science $(M=3.75)$, horticulture $(M=3.72)$, agricultural mechanics/engineering $(M=3.65)$, botany/plant science $(M=3.62)$, and crop science $(M=3.62)$ had the highest means, indicating that teachers rated themselves as "applied, knowledgeable" on these topics. The topics of forestry science $(M=3.48)$, environmental science $(M=3.41)$, aquaculture $(M=3.35)$, hydroponics $(\mathrm{M}=3.27)$, food science $(\mathrm{M}=3.27)$, and plant pathology $(\mathrm{M}=3.08)$ had means between 2.51 and 3.50 indicating that teachers perceived themselves as having "read about, possess some knowledge" about these topics. Soil science $(M=3.87)$ had the highest mean value. Plant pathology $(\mathrm{M}=3.08)$ had the lowest mean value. 
Table 19

$\underline{\text { Means and Standard Deviations for Agriscience Knowledge ( } \mathrm{n}=62)}$

\begin{tabular}{llll}
\hline Topics & $\underline{\mathrm{f}}$ & $\underline{\mathrm{M}}$ & $\underline{\mathrm{SD}}$ \\
\hline Soil Science & 61 & 3.87 & 0.34 \\
Animal and Vet Science & 61 & 3.75 & 0.43 \\
Horticulture & 60 & 3.72 & 0.49 \\
Agriculture Engineering/Mechanics & 60 & 3.65 & 0.61 \\
Botany/Plant Science & 61 & 3.62 & 0.55 \\
Crop Science & 60 & 3.62 & 0.56 \\
Forestry Science & 61 & 3.48 & 0.65 \\
Environmental Science & 59 & 3.41 & 0.67 \\
Aquaculture & 60 & 3.35 & 0.76 \\
Hydroponics & 60 & 3.27 & 0.8 \\
Food Science & 59 & 3.27 & 0.72 \\
Plant Pathology & 60 & 3.08 & 0.81 \\
\hline
\end{tabular}

$1=$ No knowledge

$2=$ Heard about, but very little knowledge

$3=$ Read about, possess some knowledge

4=Applied, knowledgeable

The number and percent of agricultural education teachers reporting their level of knowledge in twelve agriscience areas is reported in Table 20.

Hydroponics and Plant Pathology were the only two subjects that had one person indicate that they had no knowledge. Twenty-four percent of the teachers said they had heard and read about, but had very little knowledge about animal and vet science, while $75 \%$ said they had applied and were knowledgeable about animal and vet science. Eighty-six percent indicated they had applied and were knowledgeable about soil science. 
Table 20

Frequencies of Agriscience Knowledge

\begin{tabular}{|c|c|c|c|c|c|c|c|c|}
\hline \multirow[b]{2}{*}{ Topics } & \multicolumn{2}{|c|}{ No Knowledge } & \multicolumn{2}{|c|}{ Little Knowledge } & \multicolumn{2}{|c|}{ Some Knowledge } & \multicolumn{2}{|c|}{ Knowledgeable } \\
\hline & $\underline{f}$ & $\%$ & $\underline{f}$ & $\%$ & $\underline{\mathrm{f}}$ & $\%$ & $\underline{f}$ & $\%$ \\
\hline Soil Science & 0 & 0.0 & 0 & 0.0 & 8 & 12.9 & 53 & 85.5 \\
\hline Botany/Plant Science & 0 & 0.0 & 2 & 3.2 & 19 & 30.6 & 40 & 64.5 \\
\hline Hydroponics & 1 & 1.6 & 10 & 16.1 & 21 & 33.9 & 28 & 45.2 \\
\hline Aquaculture & 0 & 0.0 & 10 & 16.1 & 19 & 30.6 & 31 & 50.0 \\
\hline Animal and Vet Science & 0 & 0.0 & 15 & 24.2 & 0 & 0.0 & 46 & 74.2 \\
\hline Forestry Science & 0 & 0.0 & 5 & 8.1 & 22 & 35.5 & 34 & 54.8 \\
\hline Environmental Science & 0 & 0.0 & 6 & 9.7 & 23 & 37.1 & 30 & 48.4 \\
\hline Agriculture & & & & & & & & \\
\hline Engineering/Mechanics & 0 & 0.0 & 4 & 6.5 & 13 & 21.0 & 43 & 69.4 \\
\hline Food Science & 0 & 0.0 & 9 & 14.5 & 25 & 40.3 & 25 & 40.3 \\
\hline Plant Pathology & 1 & 1.6 & 14 & 22.6 & 24 & 38.7 & 21 & 33.9 \\
\hline Horticulture & 0 & 0.0 & 1 & 1.6 & 15 & 24.2 & 44 & 71.0 \\
\hline Crop Science & 0 & 0.0 & 2 & 3.2 & 19 & 30.6 & 39 & 62.9 \\
\hline \multicolumn{9}{|l|}{ 1=No knowledge } \\
\hline \multicolumn{9}{|c|}{$2=$ Heard about, but very little knowledge } \\
\hline \multicolumn{9}{|c|}{ 3=Read about, possess some knowledge } \\
\hline \multicolumn{9}{|c|}{ 4=Applied, knowledgeable } \\
\hline
\end{tabular}

The number and percent of agricultural education teachers reporting the teaching methods by which they teach agriscience topics is found in Table 21.

Twenty-seven percent of the teachers reported that they do not teach aquaculture.

Twenty-four percent indicated that they did not teach food science. Twenty-one percent reported that they did not teach hydroponics. In eight of the twelve areas, $50 \%$ or more of the teachers indicated that their students had applied what they learned. In all of the agriscience areas, 50\% or more of the teachers used lecture/discussion to deliver the material. 
Table 21

Frequencies of Agriscience Teaching Methods

\begin{tabular}{|c|c|c|c|c|c|c|c|c|c|c|}
\hline \multirow[b]{2}{*}{ Topics } & \multicolumn{2}{|c|}{ Don't Teach } & \multicolumn{2}{|c|}{ Lecture/Discussion } & \multicolumn{2}{|c|}{ Demonstration } & \multicolumn{2}{|c|}{ Student Applied } & \multicolumn{2}{|c|}{ Problem Solving } \\
\hline & $\underline{\mathrm{f}}$ & $\%$ & $\underline{\mathrm{f}}$ & $\%$ & $\underline{\mathrm{f}}$ & $\%$ & $\underline{\mathrm{f}}$ & $\%$ & $\underline{\mathrm{f}}$ & $\%$ \\
\hline Soil Science & 3 & 4.8 & 42 & 67.7 & 42 & 67.7 & 44 & 71.0 & 40 & 64.5 \\
\hline Botany/Plant Science & 2 & 3.2 & 41 & 66.1 & 38 & 61.3 & 37 & 59.7 & 32 & 51.6 \\
\hline Hydroponics & 13 & 21.0 & 35 & 56.5 & 26 & 41.9 & 26 & 41.9 & 21 & 33.9 \\
\hline Aquaculture & 17 & 27.4 & 38 & 61.3 & 28 & 45.2 & 28 & 45.2 & 22 & 35.5 \\
\hline Animal and Vet Science & 6 & 9.7 & 41 & 66.1 & 38 & 61.3 & 37 & 59.7 & 32 & 51.6 \\
\hline Forestry Science & 8 & 12.9 & 41 & 66.1 & 31 & 50.0 & 37 & 59.7 & 29 & 46.8 \\
\hline $\begin{array}{l}\text { Environmental Science } \\
\text { Agriculture }\end{array}$ & 6 & 9.7 & 43 & 69.4 & 24 & 38.7 & 31 & 50.0 & 24 & 38.7 \\
\hline Engineering/Mechanics & 7 & 11.3 & 39 & 62.9 & 42 & 67.7 & 43 & 69.4 & 39 & 62.9 \\
\hline Food Science & 15 & 24.2 & 33 & 53.2 & 22 & 35.5 & 23 & 37.1 & 17 & 27.4 \\
\hline Plant Pathology & 11 & 17.7 & 35 & 56.5 & 18 & 29.0 & 17 & 27.4 & 15 & 24.2 \\
\hline Horticulture & 6 & 9.7 & 43 & 69.4 & 42 & 67.7 & 40 & 64.5 & 39 & 62.9 \\
\hline Crop Science & 9 & 14.5 & 39 & 62.9 & 29 & 46.8 & 31 & 50.0 & 26 & 41.9 \\
\hline
\end{tabular}




\section{Relationships Between Key Demographic Areas of Agriscience Level of Knowledge}

The level of agriscience knowledge was correlated with the key demographic variables. Table 22 displays the magnitude and significance between the knowledge levels of the twelve agriscience topics and the demographics areas of years of experience, owing a farm, owning an agribusiness and degree held.

A negligible relationship (Kendall's tau-c) existed between years of teaching experience and five of the twelve agriscience topics. A low relationship (Kendall's tau-c) existed between years of teaching experience and the remaining agriscience topics of: environmental science (.25), botany/plant science (.21), animal and vet science (.21), food science (.17), aquaculture (.13), soil science (.13), and hydroponics (.12). The agriscience topics of botany/plant science and environmental science were significant at the .05 level. Seventy-five percent of the teachers with 15 years of experience or more indicated that they had applied and were knowledgeable about botany and plant science. Sixty percent of the teachers with eight years of experience or more reported that they had applied and were knowledgeable about environmental science.

A negligible relationship (Cramer's V) existed between owning a farm and the agriscience topics of botany/plant science (.07), animal and vet science (-.013), and soil science (-.179). A low relationship (Cramer's V) existed between owning a farm and seven of the twelve agriscience topics. A moderate relationship (Cramer's V) existed between owning a farm and food science (.33) and environmental science (.30). The relationship between owning a farm and the topic of food science was significant at the .05 level.

A negligible relationship (Cramer's V) existed between owning an agribusiness and the agriscience topics of soil science (.08) and animal and vet science (.02). A low relationship (Cramer's V) existed between owning an agribusiness and seven of the twelve agriscience topics. 
A moderate relationship (Cramer's V) existed between owning an agribusiness and plant pathology (.32), forestry science (.32), and horticulture (.30). The topic of forestry science was significant at the .05 level. Seventy-seven percent of the teachers that owned an agribusiness indicated that they had applied and were knowledgeable about forestry science.

A negligible relationship (Cramer's V) existed between highest degree held and the agriscience topic of soil science (.06). The remaining eleven topics had a low relationship (Cramer's V) with highest degree held. 
Table 22

$\underline{\text { Relationships Between Key Demographic Areas and Agriscience Knowledge }}$

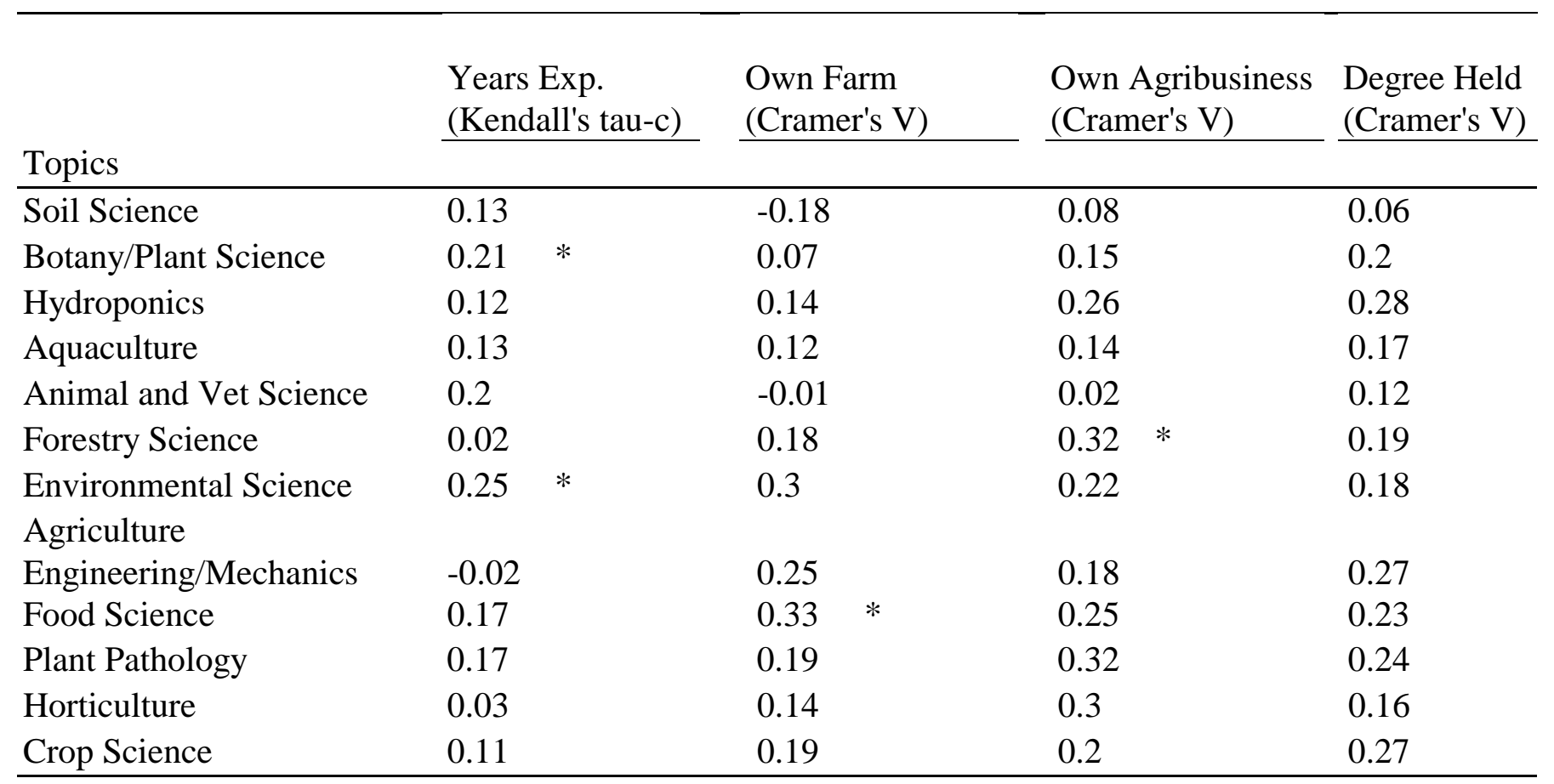

$*$ = significant at the .05 level

$* *=$ significant at the .01 level 


\section{$\underline{\text { Level of Science Knowledge }}$}

Table 23 reports the means of agricultural education teachers reporting their knowledge of science topics. Seven key science areas were given for teachers to evaluate their knowledge level.

Biology $(M=3.7)$ had the highest mean value, indicating that teachers perceived themselves as "applied, knowledgeable" in this area of science. Microbiology $(\mathrm{M}=2.33)$ had the lowest mean value, indicating that teachers perceived themselves as "heard about, but very little knowledge" in this area of science. Chemistry $(M=3.21)$, environmental science $(M=3.21)$, genetics $(M=2.90)$, and geology $(M=2.89)$ had mean values indicating that teachers had "took classes, possess some knowledge" in these areas of science. Physics $(M=2.75)$ had a mean value that indicated that teachers had "heard about, but very little knowledge" in this area of science.

Table 23

$\underline{\text { Means and Standard Deviations for Science Knowledge }(\mathrm{n}=62)}$

\begin{tabular}{llll}
\hline \multicolumn{1}{c}{ Topics } & $\underline{\mathrm{f}}$ & $\underline{\mathrm{M}}$ & $\underline{\mathrm{SD}}$ \\
\hline Biology & 61 & 3.7 & 0.53 \\
Chemistry & 61 & 3.21 & 0.55 \\
Environmental Science & 61 & 3.20 & 0.7 \\
Genetics & 61 & 2.90 & 0.81 \\
Geology & 61 & 2.89 & 0.82 \\
Physics & 61 & 2.75 & 0.72 \\
Microbiology & 60 & 2.33 & 0.82 \\
\hline
\end{tabular}

$1=$ No knowledge

$2=$ Heard and read about, but very little knowledge

$3=$ Took classes, possess some knowledge

4=Applied, knowledgeable 
Table 24 indicates the number and percentage of agricultural education teachers reporting their knowledge level of science. In six of seven science topics, over $60 \%$ of the teachers indicated they had taken classes and possessed some knowledge or had applied and were knowledgeable.

Table 24

Frequencies of Science Knowledge

\begin{tabular}{|c|c|c|c|c|c|c|c|c|}
\hline \multirow[b]{2}{*}{ Topics } & \multicolumn{2}{|c|}{ No Knowledge } & \multicolumn{2}{|c|}{ Little Knowledge } & \multicolumn{2}{|c|}{ Some Knowledge } & \multicolumn{2}{|c|}{ Knowledgeable } \\
\hline & $\underline{\mathrm{f}}$ & $\%$ & $\underline{\mathrm{f}}$ & $\%$ & $\underline{\mathrm{f}}$ & $\%$ & $\underline{\mathrm{f}}$ & $\%$ \\
\hline Chemistry & 0 & 0.0 & 4 & 6.5 & 40 & 64.5 & 17 & 27.4 \\
\hline Biology & 0 & 0.0 & 2 & 3.2 & 14 & 22.6 & 45 & 72.6 \\
\hline Physics & 2 & 3.2 & 19 & 30.6 & 32 & 51.6 & 8 & 12.9 \\
\hline Environmental Science & 0 & 0.0 & 10 & 16.1 & 29 & 46.8 & 22 & 35.5 \\
\hline Microbiology & 10 & 16.1 & 23 & 37.1 & 24 & 38.7 & 3 & 4.8 \\
\hline Genetics & 3 & 4.8 & 14 & 22.6 & 30 & 48.4 & 14 & 22.6 \\
\hline Geology & 4 & 6.5 & 12 & 19.4 & 32 & 51.6 & 13 & 21 \\
\hline
\end{tabular}

$1=$ No Knowledge

$2=$ Heard about, but very little knowledge

$3=$ Read about, possess some knowledge

4=Applied, knowledgeable

Relationships Between Key Demographics and Level of Science Knowledge

The level of science knowledge was correlated with the key demographic areas. Table 25 displays the magnitude and significance between the knowledge levels of the seven science topics and the demographics areas of years of experience, owing a farm, owning an agribusiness and degree held.

A negligible relationship (Kendall's tau-c) existed between years of teaching experience and the knowledge of science topics of genetics (.08), biology (.06), and geology (.02). A low relationship (Kendall's tau-c) existed between years of teaching experience and knowledge of environmental science (.25), chemistry (.21), physics (.20), and microbiology (.17). 
The topic of environmental science was significant at the .05 level. Sixty percent of the teachers that had only heard about and had very little knowledge about environmental science had seven years of experience or less.

A low relationship (Cramer's V) existed between all seven of the science topics and owning a farm. The statements ranged from .11 to .24 .

A negligible relationship (Cramer's V) existed between five of the seven science topics and owning an agribusiness. A low relationship (Cramer's V) existed between owning an agribusiness and the science topics of microbiology (.17) and physics (.14).

A low relationship (Cramer's V) existed between highest degree held and four of the seven science topics. A moderate relationship (Cramer's V) existed between highest degree held and geology (.38) and genetics (.36). A very strong relationship (Cramer's V) existed between highest degree held and microbiology (.74). The topic of microbiology was significant at the .01 level. Sixty-five percent of the agricultural education teachers that had no knowledge or had only heard about, but possessed very little knowledge, held their BS degree. 
Table 25

$\underline{\text { Relationships Between Key Demographic Areas and Science Knowledge }}$

\begin{tabular}{|c|c|c|c|c|}
\hline & $\begin{array}{l}\text { Years Exp. } \\
\text { (Kendall's tau-c) }\end{array}$ & $\begin{array}{l}\text { Own Farm } \\
(\text { Cramer's V) }\end{array}$ & $\begin{array}{l}\text { Own Agribusiness } \\
(\text { Cramer's V) }\end{array}$ & $\begin{array}{l}\text { Degree Held } \\
(\text { Cramer's V) } \\
\end{array}$ \\
\hline \multicolumn{5}{|l|}{ Topics } \\
\hline Chemistry & 0.21 & 0.19 & 0.06 & 0.28 \\
\hline Biology & 0.06 & 0.16 & 0.10 & 0.20 \\
\hline Physics & 0.20 & 0.21 & 0.14 & 0.27 \\
\hline Environmental Science & $0.25 *$ & 0.21 & 0.10 & 0.17 \\
\hline Microbiology & 0.17 & 0.14 & 0.17 & $0.74 * *$ \\
\hline Genetics & 0.08 & 0.24 & 0.07 & 0.36 \\
\hline Geology & 0.02 & 0.11 & 0.06 & 0.38 \\
\hline
\end{tabular}

$*$ = significant at the .05 level

$* *=$ significant at the .01 level

\section{$\underline{\text { Agriscience Workshops/Classes Attended }}$}

Agricultural education teachers were asked how many agriscience classes or workshops they had attended since college graduation. Sixty-seven percent indicated that they had attended six or more agriscience classes or workshops. Thirty-three percent indicated that they had attended five or less agriscience classes or workshops.

$\underline{\text { Science Classes/Workshops }}$

Agricultural education teachers were asked how many science classes or workshops they had attended since college graduation. Fifty-five percent indicated that they had never attended a science class or workshop. Twenty-four percent of the teachers had attended one or two science classes or workshops. Twenty-one percent indicated that they had attended three or more science classes and workshops. 


\section{Attitudes Toward Agriscience}

Agricultural education teachers were asked seven questions to determine their attitudes toward agriscience. The statement, "WV agriculture education programs should teach only agriscience courses, had a mean of 3.0 indicating that the teachers did not agree with this statement. The statements, "All WV agriculture education programs should teach agriscience courses" (M=1.38) and "WV agricultural education teachers should have the option to be dual certified in science and Ag-Ed."(M=1.46) had means below 1.50 indicating that teachers strongly agreed with these statements. The remaining statements had mean values between 1.58 and 2.02 indicating that the teachers agreed with the statements. The mean values are recorded in Table 26.

Table 26

$\underline{\text { Means and Standard Deviations for Agriscience Attitudes }}$ $\underline{(n=62)}$

\begin{tabular}{lrr}
\hline Topics & $\underline{\mathrm{f}}$ & $\underline{\mathrm{SD}}$ \\
\hline WV agriculture education programs should teach only & & \\
agriscience courses. & 60 & 3.000 .84 \\
Agriscience courses are equally enriched with science concepts across WV. & 59 & 2.020 .96 \\
WV agriculture education teachers should be dual certified in & & \\
science and AgEd. & 59 & 1.860 .82 \\
Agriscience should be taught at the middle school level. & 60 & 1.700 .77 \\
WV agriscience courses should receive science credit. & 59 & 1.580 .62 \\
WV agriculture education teachers should have the option to be dual certified in & 59 & 1.460 .60 \\
science and AgEd. & 60 & 1.380 .61 \\
All WV agriculture programs should teach agriscience courses. & & \\
\hline 1=Strongly agree & & \\
2=Agree & & \\
3=Disagree & & \\
4=Strongly disagree & &
\end{tabular}


The number and percentage of agricultural education teachers reporting their responses to seven statements about agriscience is reported in Table 27. Ninety percent of the teachers strongly agreed or agreed that "All WV agriculture education programs should teach agriscience courses." Ninety-four percent of the teachers strongly agreed or agreed that "WV agriculture education teachers should have the option to be dual certified in science and Ag-Ed." Ninety-two percent of the teachers strongly agreed or agreed that "WV agriscience courses should receive science credit." Seventy-nine percent of the teachers strongly disagreed or disagreed with the statement "WV agriculture education programs should teach only agriscience courses." 
Table 27

$\underline{\text { Frequencies of Agriscience Attitudes }}$

\begin{tabular}{|c|c|c|c|c|c|c|c|c|}
\hline \multirow[b]{2}{*}{ Statements } & \multicolumn{2}{|c|}{ Strongly Agree } & \multicolumn{2}{|c|}{$\underline{\text { Agree }}$} & \multicolumn{2}{|c|}{ Disagree } & \multicolumn{2}{|c|}{ Strongly Disagree } \\
\hline & $\underline{f}$ & $\%$ & $\underline{f}$ & $\%$ & $\underline{\mathrm{f}}$ & $\%$ & $\underline{\mathrm{f}}$ & $\%$ \\
\hline $\begin{array}{l}\text { All WV agriculture programs should teach agriscience } \\
\text { courses. }\end{array}$ & 41 & 66.1 & 15 & 24.2 & 4 & 6.5 & 0 & 0 \\
\hline Agriscience should be taught at the middle school level. & 28 & 45.2 & 23 & 37.1 & 8 & 12.9 & 1 & 1.6 \\
\hline $\begin{array}{l}\text { WV agriculture programs should teach only agriscience } \\
\text { courses. } \\
\text { WV agriscience courses should receive science credit. }\end{array}$ & $\begin{array}{r}5 \\
28\end{array}$ & $\begin{array}{r}8.1 \\
45.2\end{array}$ & $\begin{array}{c}6 \\
29\end{array}$ & $\begin{array}{r}9.7 \\
46.8\end{array}$ & $\begin{array}{r}33 \\
1\end{array}$ & $\begin{array}{r}53.2 \\
1.6\end{array}$ & $\begin{array}{r}16 \\
1\end{array}$ & $\begin{array}{r}25.8 \\
1.6\end{array}$ \\
\hline $\begin{array}{l}\text { Agriscience courses are equally enriched with science } \\
\text { concepts across WV. }\end{array}$ & 21 & 33.9 & 21 & 33.9 & 12 & 19.4 & 5 & 8.1 \\
\hline $\begin{array}{l}\text { WV agriculture teachers should be dual certified in } \\
\text { science and AgEd. }\end{array}$ & 23 & 37.1 & 22 & 35.5 & 13 & 21.0 & 1 & 1.6 \\
\hline $\begin{array}{l}\text { WV agriculture teachers should have the option to be } \\
\text { dual certified in science and AgEd. }\end{array}$ & 34 & 54.8 & 24 & 38.7 & 0 & 0 & 1 & 1.6 \\
\hline
\end{tabular}

$1=$ Strongly agree

2=Agree

$3=$ Disagree

$4=$ Strongly disagree 


\section{$\underline{\text { Relationships Between Key Demographic Areas and Agriscience Attitudes }}$}

The responses to seven agriscience statements by agricultural education teachers were correlated with the key demographic areas. The magnitude and significance between the seven statements and the demographic areas of years of experience, owning a farm, owning an agribusiness and highest degree held is displayed in Table 28.

A negligible relationship (Kendall's tau-c) existed between years of experience and all seven agriscience attitude statements. The statement "WV agriculture programs should teach only agriscience courses" was significant at the .01 level. Eighty percent of the respondents that strongly agreed with the statement "WV agriculture education programs should teach only agriscience courses" had twenty-two years of teaching experience or more.

A low relationship (Cramer's V) existed between owning a farm and six of the seven agriscience attitude statements. A moderate relationship (Cramer's V) existed between owning a farm and the statement "Agriscience should be taught at the middle school level" (.33).

A low relationship (Cramer's $\mathrm{V}$ ) existed between owning an agribusiness and six of the seven agriscience attitude statements. A moderate relationship (Cramer's V) existed between owning an agribusiness and the statement "WV agriculture education teachers should have the option to be dual certified in science and Ag-Ed" (.35).

A low relationship (Cramer's V) existed between highest degree held and six of the seven agriscience attitude statements. A substantial relationship (Cramer's V) existed between highest degree held and the statement "WV agriculture education programs should teach only agriscience courses" (.53). This statement was also significant at the .01 level. Eighty-seven percent of agriculture education teachers holding their BS degree strongly agreed or agreed with the statement "Agriscience should be taught at the middle school level." 
Table 28

Relationships Between Key Demographic Areas and Agriscience $\underline{\text { Attitudes }}$

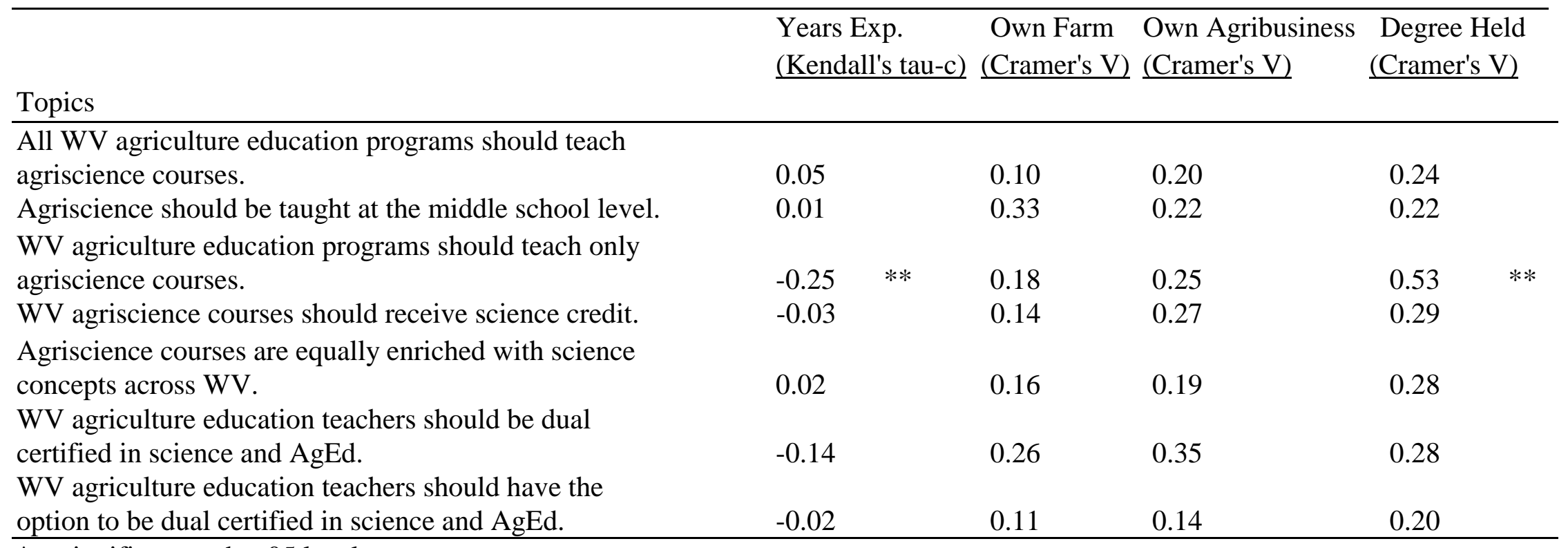




\section{$\underline{\text { Agriscience Teaching Attitudes }}$}

Table 29 contains the mean levels for the attitudes of agricultural education teachers in the area of teaching agriscience. Teachers had to respond to ten statements that started with. "It is my job to..."

Six of the ten statements had mean values ranging from 1.73 to 2.45 indicating that the teachers agreed with these statements. Teachers strongly agreed with the following "It is my job to..." statements: "to teach high school students about agriscience"( $\mathrm{M}=1.35)$, "to involve students in agriscience related SAEs" $(M=1.45)$, and "to develop instructional materials and lesson plans on agriscience" $(\mathrm{M}=1.50)$. Teachers disagreed with the "It is my job to..." statement, "develop publications about agriscience"( $\mathrm{M}=2.52)$.

Table 29

$\underline{\text { Means and Standard Deviations for Agriscience Teaching Attitudes }}(\mathrm{n}=62)$

\begin{tabular}{llll} 
It is my job to... & $\underline{\mathrm{f}}$ & $\underline{\mathrm{M}}$ & $\underline{\mathrm{SD}}$ \\
\hline develop publications about agriscience. & 60 & 2.52 & 0.83 \\
to conduct agriscience research & 60 & 2.45 & 0.89 \\
to distribute publications about agriscience & 60 & 2.23 & 0.79 \\
to educate consumers about agriscience & 60 & 2.22 & 0.78 \\
to sponsor meeting related to agriscience & 60 & 2.22 & 0.76 \\
to educate public policy makers about agriscience & 60 & 2.05 & 0.79 \\
to educate farmers and agriculturists & 60 & 1.73 & 0.69 \\
to develop instructional materials and lesson plans on agriscience & 60 & 1.50 & 0.54 \\
to involve students in agriscience related SAEs & 60 & 1.45 & 0.59 \\
to teach high school students about agriscience & 60 & 1.35 & 0.52 \\
\hline
\end{tabular}

$1=$ Strongly agree

$2=$ Agree

$3=$ Disagree

$4=$ Strongly disagree 
Table 30 contains the number and percentage of agricultural education teachers reporting their responses to the ten statements concerning their responsibility with agriscience. Ninety-five percent of the teachers strongly agreed or agreed that it was their job to teach high school students about agriscience. Ninety-five percent strongly agreed or agreed that it was their job to develop instructional materials and lesson plans on agriscience. Ninety-two percent strongly agreed or agreed that it was their job to involve students in agriscience related SAEs. Eightythree percent strongly agreed or agreed that it was their job to educate farmers and agriculturists about agriscience. Fifty-eight percent of the agricultural education teachers strongly disagreed or agreed that it was their job to develop publications about agriscience. Fifty-three percent strongly disagreed or disagreed that it was their job to conduct agriscience research. 
Table 30

Frequencies of Agriscience Teaching Attitudes

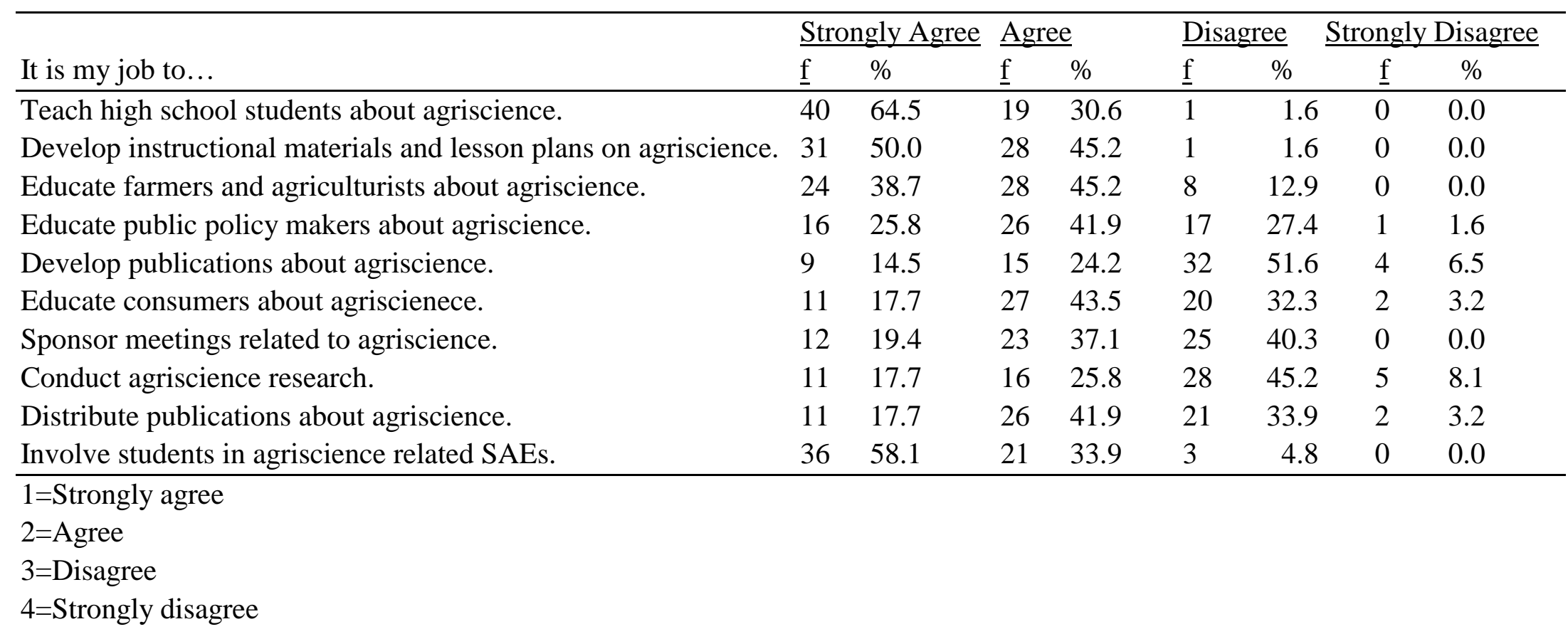




\section{$\underline{\text { Relationships Between Key Demographic Areas and Agriscience Teaching Attitudes }}$}

The agriscience teaching attitudes reported by teachers were correlated with the key demographic areas. The magnitude and significance between the ten agriscience responsibilities and the demographic areas of year of experience, owning a farm, owning an agribusiness, and highest degree held is displayed in Table 31.

A negligible relationship (Kendall's tau-c) existed between years of experience and all ten teaching attitude statements. The "It is my job to..." statement "to educate public policy makers about agriscience" was significant at the .01 level. Eighty-seven percent of the agricultural education teachers that strongly agreed with the "It is my job to..." statement "to educate public policy makers about agriscience" had fifteen years of experience or more.

A low relationship (Cramer's V) existed between owning a farm and six of the ten agricience teaching attitude statements. A moderate relationship (Cramer's V) existed between owning a farm and the following "It is my job to..." statements: "conduct agriscience research" (.43), "develop publications about agriscience" (.40), "distribute publications about agriscience" (.34), and "educate consumers about agriscience" (.30).

The relationship between "It is my job to..." statement "conduct agriscience research and owning a farm was significant at the .01 level and the relationship between "develop publications about agriscience" and owning a farm was significant at the .05 level. Fifty percent of those teachers that owned a farm as opposed to $35 \%$ of those that did not own a farm, strongly agreed or agreed that it was their job to conduct agriscience research. Sixty percent of the teachers that owned a farm disagreed that it was their job to develop publications about agriscience.

A low relationship (Cramer's V) existed between owning an agribusiness and all ten "It is my job to..." statements. 
A low relationship (Cramer's V) existed between highest degree held and five of the ten "It is my job to..." statements. A moderate relationship (Cramer's V) existed between highest degree held and the following "It is my job to..." statements: "educate consumers about agriscience" (.45), “distribute publications about agriscience” (.40), “develop publications about agriscience" (.37), "conduct agriscience research" (.32), and "educate farmers and agriculturists about agriscience" (.30). 
Table 31

$\underline{\text { Relationships Between Key Demographic Areas and Agriscience Teaching Attitudes }}$

\begin{tabular}{|c|c|c|c|c|}
\hline \multirow{2}{*}{ It is my job to... } & $\frac{\text { Years Exp. }}{(\text { Kendall's tau-c) }}$ & $\frac{\text { Own Farm }}{(\text { Cramer's V) }}$ & $\frac{\text { Own Agribusiness }}{\text { (Cramer's V) }}$ & $\frac{\text { Degree Held }}{\text { (Cramer's V) }}$ \\
\hline & & & & \\
\hline teach high school students about agriscience. & -0.05 & 0.21 & 0.10 & 0.17 \\
\hline educate farmers and agriculturists about agriscience. & -0.20 & 0.07 & 0.09 & 0.30 \\
\hline educate public policy makers about agriscience. & $-0.26 * *$ & 0.22 & 0.15 & 0.29 \\
\hline sponsor meetings related to agriscience. & -0.17 & 0.18 & 0.16 & 0.27 \\
\hline conduct agriscience research. & -0.08 & 0.43 & 0.28 & 0.32 \\
\hline distribute publications about agriscience. & $-0.45 * *$ & 0.34 & 0.18 & 0.40 \\
\hline involve students in agriscience related SAEs. & 0 & 0.17 & 0.08 & 0.17 \\
\hline
\end{tabular}

It is my job to...

$*$ = significant at the .05 level

$* *=$ significant at the .01 level 


\section{Implementation of Agriscience}

The means for barriers of agriscience implementation is displayed in Table 32.

Agricultural education teachers responded to a list of nine potential barriers of teaching agriscience.

All nine barriers were considered to be minor. Their mean values ranged from 1.79 to 2.41. Classroom/Lab space $(M=2.41)$ had the highest mean, while administration acceptance $(\mathrm{M}=1.79)$ had the lowest mean.

Table 32

Means and Standard Deviations for Agriscience Implementation Barriers ( $\mathrm{n}=62)$

\begin{tabular}{llll}
\hline \multicolumn{1}{c}{ Barrier } & $\underline{\mathrm{f}}$ & $\underline{\mathrm{M}}$ & $\underline{\mathrm{SD}}$ \\
\hline Classroom/Lab Space & 61 & 2.41 & 0.97 \\
Equipment & 61 & 2.34 & 0.96 \\
Instructional Materials & 61 & 2.34 & 0.89 \\
Time & 61 & 2.23 & 0.86 \\
Textbooks & 61 & 2.18 & 0.96 \\
Student Academic Ability & 60 & 2.17 & 0.85 \\
Teacher Knowledge & 61 & 1.98 & 0.96 \\
Community & 61 & 1.89 & 0.88 \\
Administration Acceptance & 61 & 1.79 & 0.92 \\
\hline 1=Not at all & & & \\
2=Minor & & & \\
3=Moderate & & &
\end{tabular}

Table 33 contains the number and percentage of agricultural education teachers reporting their responses to the nine barriers of teaching agriscience. Seventy-nine percent of the agricultural education teachers indicated that administration acceptance of teaching agriscience was not at all or a minor barrier. Seventy-six percent of the teachers indicated that community support of teaching agriscience was not at all or a minor barrier. Forty-five percent of the 
agricultural education teachers indicated that classroom/lab space was a moderate or major barrier to teaching agriscience. Thirty-nine percent of the teachers indicated that instructional material on agriscience was a moderate or major barrier. Thirty-five percent of the teachers indicated that agriscience equipment was a moderate or major barrier.

Table 33

Frequencies of Agriscience Implementation Barriers

\begin{tabular}{lllllllll}
\hline \multirow{2}{*}{ Barrier } & \multicolumn{2}{l}{ Not at all } & \multicolumn{2}{c}{ Minor } & \multicolumn{2}{c}{ Moderate } & \multicolumn{2}{c}{ Major } \\
\hline Equipment & $\underline{\mathrm{f}}$ & $\%$ & $\underline{\mathrm{f}}$ & $\%$ & $\underline{\mathrm{f}}$ & $\%$ & $\underline{\mathrm{f}}$ & $\%$ \\
Instructional Materials & 11 & 17.7 & 28 & 45.2 & 12 & 19.4 & 10 & 16.1 \\
Textbooks & 10 & 16.1 & 27 & 43.5 & 17 & 27.4 & 7 & 11.3 \\
Student Academic Ability & 16 & 25.8 & 25 & 40.3 & 13 & 21.0 & 7 & 11.3 \\
Teacher Knowledge & 21.0 & 28 & 45.2 & 15 & 24.2 & 4 & 6.5 \\
Time & 24 & 38.7 & 18 & 29.0 & 15 & 24.2 & 4 & 6.5 \\
Classroom/Lab Space & 12 & 19.4 & 28 & 45.2 & 16 & 25.8 & 5 & 8.1 \\
Community & 12 & 19.4 & 21 & 33.9 & 19 & 30.6 & 9 & 14.5 \\
Administration Acceptance & 24 & 38.7 & 23 & 37.1 & 11 & 17.7 & 3 & 4.8 \\
\hline
\end{tabular}

$1=$ Not at all

2=Minor

$3=$ Moderate

4=Major

$\underline{\text { Relationships Between Key Demographic Areas and Agriscience Barriers }}$

The agriscience teaching barriers reported by teachers were correlated with the key demographic areas. Table 34 displays the magnitude and significance between the ten agriscience barriers and the demographic areas of year of experience, owning a farm, owning an agribusiness, and highest degree held.

A negligible relationship (Kendall's tau-c) existed between years of experience and seven of the nine agriscience barriers. A low relationship (Kendall's tau-c) existed between years of experience and the barrier of time (.21) and administration acceptance (.11). 
The barrier of time was significant at the .05 level. Of the teachers that indicated time was a major barrier, $100 \%$ had fifteen years of experience or more.

A low relationship (Cramer's V) existed between owning a farm and eight of the nine agriscience barriers. A moderate relationship (Cramer's V) existed between owning a farm and the agriscience barrier of administration acceptance (.37). This barrier was also significant at the .05 level.

A negligible to low relationship (Cramer's V) existed between owning an agribusiness and all nine agriscience barriers. They ranged from .07 to .28 .

A low relationship (Cramer's V) existed between highest degree held and five of the nine agriscience barriers. A moderate relationship (Cramer's V) existed between highest degree held and the barriers of time (.45), textbooks (.34), equipment (.30), and administration acceptance (.30). 
Table 34

$\underline{\text { Relationships Between Key Demographic Areas and Agriscience Implementation Barriers }}$

\begin{tabular}{lllll}
\hline & $\begin{array}{c}\text { Years Exp. } \\
(\text { Kendall's tau-c })\end{array}$ & $\begin{array}{l}\text { Own Farm } \\
(\text { Cramer's V })\end{array}$ & $\begin{array}{l}\text { Own Agribusiness } \\
(\text { Cramer's V })\end{array}$ & $\begin{array}{l}\text { Degree Held } \\
\text { (Cramer's V })\end{array}$ \\
\cline { 2 - 3 } Barrier & -0.04 & 0.18 & 0.27 & 0.30 \\
Equipment & 0.01 & 0.14 & 0.28 & 0.26 \\
Instructional Materials & -0.07 & 0.18 & 0.07 & 0.34 \\
Textbooks & 0.00 & 0.17 & 0.15 & 0.23 \\
Student Academic Ability & 0.10 & 0.27 & 0.17 & 0.21 \\
Teacher Knowledge & $0.21 *$ & 0.16 & 0.15 & 0.45 \\
Time & -0.09 & 0.24 & 0.08 & 0.29 \\
Classroom/Lab Space & -0.01 & 0.28 & 0.28 & 0.24 \\
Community & 0.11 & $0.37 *$ & 0.13 & 0.30 \\
Administration Acceptance & & & & \\
\hline
\end{tabular}

$*=$ significant at the .05 level

$* *$ = significant at the .01 level 
Implementation of Agriscience - Receiving Information

The means that agricultural education teachers reported on how they would prefer to receive agriscience information is reported in Table 35. Teachers responded to a list of nine sources of information for agriscience.

Agricultural education teachers agreed that they would prefer to receive information about agriscience from eight of the nine information sources. Those information sources had mean values that ranged from 1.70 to 2.02. The information source of workshops $(\mathrm{M}=1.46)$ had the highest mean, indicating that agricultural education teaches strongly agree with receiving information about agriscience through workshops.

Table 35

Means and Standard Deviations for Agriscience Implementation - Receiving Information ( $\mathrm{n}=62)$

\begin{tabular}{llll}
\hline Information Source & $\underline{\mathrm{f}}$ & $\underline{\mathrm{M}}$ & $\underline{\mathrm{SD}}$ \\
\hline Internet & 61 & 2.02 & 0.83 \\
Slide sets/movies & 61 & 2.00 & 0.84 \\
CD-Rom & 61 & 1.90 & 0.81 \\
Computer Programs & 61 & 1.84 & 0.69 \\
Lesson Plans & 61 & 1.80 & 0.65 \\
University Courses & 61 & 1.79 & 0.82 \\
Textbooks & 61 & 1.74 & 0.60 \\
Video Tapes & 61 & 1.70 & 0.64 \\
Workshops & 61 & 1.46 & 0.62 \\
\hline 1=Strongly agree & & & \\
2=Agree & & & \\
3=Disagree & & &
\end{tabular}


The number and percentage of agricultural education teachers reporting their responses to the nine information sources of agriscience is contained in Table 36. Ninety-five percent of the agricultural education teachers strongly agreed or agreed that they prefer to receive agriscience information from workshops. Ninety-three percent of the teachers strongly agreed or agreed that they prefer to receive agriscience information from textbooks. Ninety-two percent of the teachers strongly agreed or agreed that they prefer to receive agriscience information from videotapes.

Twenty-four percent of the agricultural education teachers strongly disagreed or disagreed that they prefer to receive agriscience information from slide sets/movies. Twenty-three percent of the teachers strongly disagreed or disagreed that they prefer to receive agriscience information from the Internet.

Table 36

Frequencies of Agriscience Implementation - Receiving Information

\begin{tabular}{|c|c|c|c|c|c|c|c|c|}
\hline \multirow[b]{2}{*}{ Information Source } & \multicolumn{2}{|c|}{$\underline{\text { Strongly Agree }}$} & \multicolumn{2}{|c|}{ Agree } & \multicolumn{2}{|c|}{ Disagree } & \multicolumn{2}{|c|}{ Strongly Disagree } \\
\hline & $\underline{f}$ & $\%$ & $\underline{\mathrm{f}}$ & $\%$ & $\underline{f}$ & $\%$ & $\underline{\mathrm{f}}$ & $\%$ \\
\hline Internet & 16 & 25.8 & 32 & 51.6 & 9 & 14.5 & 4 & 6.5 \\
\hline Workshops & 36 & 58.1 & 23 & 37.1 & 1 & 1.6 & 1 & 1.6 \\
\hline Video Tapes & 23 & 37.1 & 34 & 54.8 & 3 & 4.8 & 1 & 1.6 \\
\hline Slide sets/movies & 18 & 29.0 & 28 & 45.2 & 12 & 19.4 & 3 & 4.8 \\
\hline University courses & 24 & 38.7 & 30 & 48.4 & 3 & 4.8 & 4 & 6.5 \\
\hline Lesson Plans & 19 & 30.6 & 36 & 58.1 & 5 & 8.1 & 1 & 1.6 \\
\hline Textbooks & 20 & 32.3 & 38 & 61.3 & 2 & 3.2 & 1 & 1.6 \\
\hline Computer Programs & 19 & 30.6 & 34 & 54.8 & 7 & 11.3 & 1 & 1.6 \\
\hline CD-Rom & 20 & 32.3 & 30 & 48.4 & 8 & 12.9 & 3 & 4.8 \\
\hline $\begin{array}{l}\text { 1=Strongly agree } \\
\text { 2=Agree } \\
\text { 3=Disagree } \\
\text { 4=Strongly Disagree }\end{array}$ & & & & & & & & \\
\hline
\end{tabular}




\section{$\underline{\text { Relationships Between Key Demographic Areas and Receiving Agriscience Information }}$}

The preferred sources of agriscience information reported by teachers were correlated with the key demographic areas. Table 37 displays the magnitude and significance between the nine sources of agriscience information and the demographic areas of year of experience, owning a farm, owning an agribusiness, and highest degree held.

A negligible relationship (Kendall's tau-c) existed between years of experience and six of the nine sources of agriscience information. A low relationship (Kendall's tau-c) existed between years of experience and the information sources of lesson plans (.15), the Internet (.11), and workshops (.10).

A negligible relationship (Cramer's V) existed between owning a farm and the agriscience information source of university courses (.06). A low relationship (Cramer's V) existed between owning a farm and eight of the nine sources of agriscience information.

A low relationship (Cramer's V) existed between owning and agribusiness and all nine agriscience information sources. They ranged from .11 to .29.

A low relationship (Cramer's V) existed between highest degree held and five of the nine agriscience information sources. A moderate relationship (Cramer's V) existed between highest degree held and the agriscience information sources of lesson plans (.42), slide sets/movies (.38), computer programs (.31), and university courses (.30). 
Table 37

$\underline{\text { Relationships Between Key Demographic Areas and Agriscience Implementation - Receiving Information }}$

\begin{tabular}{|c|c|c|c|c|}
\hline & $\begin{array}{l}\text { Years Exp. } \\
\text { (Kendall's tau-c) }\end{array}$ & $\begin{array}{l}\text { Own Farm } \\
(\text { Cramer's V) } \\
\end{array}$ & $\begin{array}{l}\text { Own Agribusiness } \\
\text { (Cramer's V) }\end{array}$ & $\begin{array}{l}\text { Degree Held } \\
(\text { Cramer's V) } \\
\end{array}$ \\
\hline \multicolumn{5}{|l|}{ Information Source } \\
\hline Internet & 0.11 & 0.29 & 0.11 & 0.28 \\
\hline Workshops & 0.10 & 0.24 & 0.11 & 0.23 \\
\hline Video Tapes & -0.06 & 0.12 & 0.24 & 0.23 \\
\hline Slide sets/movies & 0.05 & 0.22 & 0.29 & 0.38 \\
\hline University courses & 0.04 & 0.06 & 0.16 & 0.30 \\
\hline Lesson Plans & 0.15 & 0.16 & 0.23 & 0.42 \\
\hline Textbooks & -0.13 & 0.11 & 0.19 & 0.24 \\
\hline Computer Programs & 0.00 & 0.28 & 0.23 & 0.31 \\
\hline CD-Rom & 0.07 & 0.15 & 0.24 & 0.25 \\
\hline
\end{tabular}




\section{CHAPTER V}

\section{SUMMARY, CONCLUSIONS, AND RECOMMENDATIONS}

The purpose of the study was to provide information to the state supervisor of agricultural education and teacher educators that may be useful in modifying undergraduate course requirements and in planning in-service workshops and graduate courses to enhance teacher knowledge. To accomplish this purpose, 95 West Virginia agricultural education teachers were surveyed to ascertain their knowledge, attitudes, and implementation of biotechnology and agriscience.

The primary objective of this study was to describe West Virginia agricultural education teachers' attitudes toward and knowledge level of biotechnology and agriscience as well as activities which demonstrate implementation of biotechnology and agriscience. A secondary objective was to determine relationships that exist between selected demographic teacher variables and agriscience attitudes and knowledge levels.

\section{$\underline{\text { Research Questions }}$}

The following questions provided direction for the study:

1. What are the attitudes of West Virginia agricultural education teachers toward biotechnology and agriscience?

2. What level of knowledge and understanding is demonstrated by West Virginia agricultural education teachers regarding biotechnology and agriscience?

3. What teaching methods do West Virginia Agricultural Education teachers use when teaching biotechnology and agriscience? 
4. What is the perceived role of the agricultural education teacher with regard to biotechnology?

5. What barriers do agricultural education teachers face when they teach agriscience and biotechnology concepts and problems?

6. What relationships exist between selected teacher demographic variables and biotechnology attitudes and knowledge levels?

7. How do West Virginia agricultural education teachers prefer to receive biotechnology and agriscience information?

Responses of West Virginia agricultural education teachers are summarized in the following pages. Results of the data analysis are presented in the following areas: demographics of the sample group; frequency, mean, and standard deviation of biotechnology and agriscience knowledge, teaching method used, attitudes, and implementation; frequency and percent of biotechnology and agriscience knowledge, attitudes, and implementation; and relationships between biotechnology and agriscience knowledge, attitudes, and implementation and key demographic areas.

Data obtained were analyzed at West Virginia University using the Statistical Package for Social Sciences for Windows (SPSS). Data were analyzed using frequencies, percentages, means, Kendall's tau-c coefficient and Cramer's V coefficient.

\section{Demographics of the Sample Group}

The population of this study consisted of WV agricultural education teachers employed during the 2000-2001 school year. Each teacher was asked how many years they had taught, what was the highest degree they held, whether they operated a farm or an agribusiness, and what were the courses they were currently teaching. 
An existing study and questionnaire conducted by Kirby (1990) in North Carolina was modified for this research. The instrument used in the Kirby study was used to establish content validity of the data collection instrument.

A panel of experts, consisting of agricultural education teachers serving on the West Virginia Program and Policy committee, was used to pilot test the instrument. They were administered the questionnaire and the data were used to establish the instrument's reliability. Cronbach's alpha is the most widely used reliability tool. The reliability of the instrument was found to be .9026 . Sixty-two of the 95 agricultural education teachers returned the instrument resulting in a $65 \%$ response rate.

\section{Biotechnology Level of Knowledge Summary and Conclusions}

West Virginia agricultural education teachers were asked to rate their knowledge level on eighteen topics of biotechnology. In all cases a score of $1=$ no knowledge, $2=$ heard about, but very little knowledge, $3=$ read about, possess some knowledge, and $4=$ applied, knowledgeable.

West Virginia agricultural education teachers perceived themselves as having only "heard about, but very little knowledge" on the topics of bioremediation, electrophoresis, human genomics, transgenic species, recombinant DNA, and microbial biotechnology. The teachers perceived themselves as having "read about, possess some knowledge" on the topics of gene splicing, environmental biotechnology, food biotechnology, genetic engineering, genetically modified food, cloning, biotechnology ethics, plant tissue culture, resistant plant species, hybridization, and growth hormones. Animal reproduction was the only biotechnology topic that West Virginia agricultural education teachers perceived themselves as having "applied, knowledgeable." 
A substantial relationship existed between operating a farm and the topic of growth hormones. Slightly more than half of the teachers responding who operated a farm perceived themselves as having "applied, knowledgeable" about the topic of growth hormones. A moderate relationship existed between operating an agribusiness and the topic of animal reproduction. Slightly more than $90 \%$ of the teachers who operated an agribusiness perceived themselves as having "applied, knowledgeable" on the topic of animal reproduction. A substantial relationship existed between highest degree held and the biotechnology topics of transgenic species, recombinant DNA, gene splicing, and electrophoresis. Agricultural education teachers with a master's degree or higher perceived themselves as more knowledgeable on the topics of recombinant DNA and electrophoresis than teachers with bachelors degrees. Those with bachelor's degrees perceived themselves as more knowledgeable on the topic of gene splicing than did those who possessed advanced degrees.

\section{$\underline{\text { Conclusions }}$}

Based upon the biotechnology level of knowledge that West Virginia agricultural education teacher's reported, the following conclusions can be drawn:

- Teachers perceive themselves as having more knowledge on biotechnology topics that have traditionally been associated with agriculture (animal reproduction, hybridization) and less knowledge on topics that are associated with other fields (environmental biotechnology, human genomics)

- Teachers that operate a farm or agribusiness perceive themselves as more knowledgeable than those that do not on several biotechnology topics. 


\section{$\underline{\text { Summary and Conclusions of Biotechnology Teaching Methods Used }}$}

West Virginia agricultural education teachers were asked to indicate how they taught the eighteen biotechnology topics. They could select as many as applied of the following teaching techniques: don't teach, lecture/discussion, demonstration, student applied, and problem solving.

Slightly more than half of the teachers taught nine of the eighteen biotechnology topics. The topics that were taught the most were topics that teachers perceived themselves as being more knowledgeable about. Lecture/discussion was used most with the topics that were taught. Teachers teaching biotechnology topics used the teaching methods of demonstration, student application, and problem solving very little. When these techniques were used, it was with areas in which teachers perceived themselves as being more knowledgeable.

\section{$\underline{\text { Conclusions }}$}

Based on the data provided by West Virginia agricultural education teachers on the biotechnology teaching methods used, the following conclusions can be drawn:

- Teachers are teaching some biotechnology topics in their programs.

- Teachers are more likely to teach the biotechnology topics found in agriculture and tend not to include areas outside of agriculture.

- Teachers are more likely to teach biotechnology topics that they perceive themselves as having more knowledge than those topics in which they perceive themselves as having less knowledge about. 


\section{$\underline{\text { Summary and Conclusions for Biotechnology Classes/Workshops Attended }}$}

The West Virginia agricultural education teachers were asked how many biotechnology classes/workshops they have attended since college graduation. More than half had never attended a biotechnology class/workshop.

Conclusions

Based on the information provided by West Virginia agricultural education teachers on how many biotechnology classes/workshops they had attended, the following conclusions can be drawn:

- Teachers are not attending biotechnology classes/workshops when available, or

- Biotechnology classes/workshops are not being offered for teachers to attend. $\underline{\text { Summary and Conclusions for Attitudes toward Biotechnology }}$

The attitudes possessed by West Virginia agricultural education teachers of biotechnology were divided into two sections. In the first section, teachers responded to ten biotechnology issue questions. In the second section, teachers responded to ten statements that were preceded by "It is my job to..." In all cases a $1=$ strongly agree, $2=$ agree, $3=$ disagree, and $4=$ strongly disagree . In the first section, teachers agreed with almost all of the biotechnology statements. Teachers disagreed with two statements, "Crossbreeding to produce hybrids is morally wrong" and "Cloning living organisms is morally wrong." Teachers believed that biotechnology should be a class taught by agricultural education teachers and that it should be a topic in an agriscience class. A low relationship existed between years of experience and the statement, "Biotechnology should be a class taught by agricultural education teachers." Teachers with less experience (eleven years or less) agreed with this statement more than those with more experience (more than eleven years). A moderate relationship existed between operating a farm and the statement, 
"I support the use of genetic engineering of food crops." Nearly all of the teachers that did not operate a farm, agreed with this statement. A moderate relationship existed between operating an agribusiness and the statement, "Biotechnology should be a topic in an agriscience class." The entire group of teachers that operated an agribusiness, agreed with this statement. A substantial relationship existed between highest degree held and the statement, "Cloning living organisms is morally wrong." Nearly $90 \%$ of the teachers with a master's degree or higher did not feel that cloning was morally wrong.

In the second attitude section, teachers agreed that it was their job to do more than half of the biotechnology responsibilities. Teachers did not feel that it was their job to, distribute publications about biotechnology, sponsor meetings related to biotechnology, conduct biotechnology research, and develop publications about biotechnology. A moderate relationship existed between operating an agribusiness and the job of distributing publications about biotechnology and teaching high school students about biotechnology. Almost three-fourths of the teachers that operated an agribusiness believed it was their job to distribute publications about biotechnology and the entire group of agribusiness operating teachers believed it was their job to teach high school students about biotechnology. A moderate to substantial relationship existed between highest degree held and several biotechnology responsibilities. More than $60 \%$ of the teachers that held their master's degree or higher, did not feel that it was job to conduct biotechnology research, sponsor biotechnology-related meetings, or develop biotechnology publications. More than $50 \%$ of the teachers that held their bachelor's degree believed that it was their job to develop instructional materials and lesson plans on biotechnology and educate consumers about biotechnology. 


\section{$\underline{\text { Conclusions }}$}

Based on the data collected from the West Virginia agricultural education teachers concerning their attitudes about biotechnology, the following conclusions can be drawn:

- Teachers support the use of biotechnology in today's world.

- Agricultural education teachers believe that they should teach biotechnology courses and topics.

- It is more likely that teachers with less experience will teach biotechnology.

- It is more likely that teachers that operate an agribusiness will teach biotechnology.

- Teachers believe more that a biotechnology responsibility applies to their job if it involves educating people and involving students.

- Teachers do not believe that biotechnology responsibility applies to their job if it involves outside activities that do not involve students and educating people.

- It is more likely that teachers that operate an agribusiness will perform biotechnology responsibilities that do not involve students and educating people.

- It is more likely that teachers with a bachelor's degree will perform more biotechnology responsibilities than those with a master's degree or higher.

$\underline{\text { Summary and Conclusions of Implementation of Biotechnology }}$

Information on how West Virginia agricultural education teachers implement biotechnology was divided into two sections. In the first section, teachers rated nine barriers to teaching biotechnology. In all cases a $1=$ not at all, $2=$ minor, $3=$ moderate, and $4=$ major. In the second section, teachers rated how they would prefer to receive biotechnology information. In all cases a $1=$ strongly agree, $2=$ agree, $3=$ disagree, and $4=$ strongly disagree . 
In the first implementation section, teachers felt that there were many barriers to teaching biotechnology. Biotechnology equipment was the greatest barrier for teachers teaching biotechnology. They did not feel that administration acceptance and community support was a barrier. A low relationship existed between years of experience and the barrier of teacher knowledge. Nearly three-fourths of the teachers, with twelve years of experience or more, considered teacher knowledge to be a barrier.

In the second section, teachers agreed that they would prefer to receive information from many different sources. Teachers preferred workshops on biotechnology to all other information sources.

\section{$\underline{\text { Conclusions }}$}

Based on the information provided by West Virginia agricultural education teachers in the biotechnology implementation sections, the following conclusions can be drawn:

- The greatest barriers that exist for teachers teaching biotechnology are in the areas of equipment, instructional materials, and lab space.

- Teachers that have been teaching longer have missed instruction on the fairly new topics of biotechnology and consider teacher knowledge a barrier.

- It is highly likely that if biotechnology workshops were available, teachers would participate.

\section{$\underline{\text { Summary and Conclusions of Knowledge of Agriscience }}$}

West Virginia agricultural education teachers were asked to rate their knowledge level on twelve topics of agriscience. In all cases a score of $1=$ no knowledge, $2=$ heard about, but very little knowledge, 3 = read about, possess some knowledge, and $4=$ applied, knowledgeable.

Teachers perceived themselves having "read about, possess some knowledge", about the 
topics of plant pathology, food science, hydroponics, aquaculture, environmental science, and forestry science. Teachers perceived themselves as "applied, knowledgeable" about the topics of crop science, botany/plant science, agriculture mechanics/engineering, horticulture, animal and vet science, and soil science. The topic of soil science had nearly $90 \%$ of the teachers perceiving themselves as knowledgeable. A low relationship existed between years of experience and the agriscience areas of botany/plant science and environmental science. Three-fourths of the teachers with more teaching experience perceived themselves as more knowledgeable about botany and plant science. Almost two-thirds of the teachers with more teaching experience perceived themselves as more knowledgeable in the area of environmental science. A moderate relationship existed between operating an agribusiness and the topic of forestry science. A little more than three-fourths of the teachers that operated an agribusiness perceived themselves as more knowledgeable about this topic.

\section{$\underline{\text { Conclusions }}$}

Based on the information provided by West Virginia agricultural education teachers in the area of knowledge level of agriscience, the following conclusions can be drawn:

- Teachers perceive themselves as knowledgeable about agriscience.

- It is more likely that teachers with more teaching experience are more knowledgeable about several agriscience topics.

\section{$\underline{\text { Summary and Conclusions of Agriscience Teaching Methods Used }}$}

West Virginia agricultural education teachers were asked to indicate how they taught the 12 agriscience topics. They could select as many as applied of the following teaching techniques: don't teach, lecture/discussion, demonstration, student applied, and problem solving. 
The majority of the teachers reported teaching most of the agriscience topics. The areas of aquaculture, food science, and hydroponics were taught the least. The areas of soil science and botany/plant science were taught the most. In all the agriscience topics, more than half of the teachers used lecture/discussion and in more than half of the agriscience topics, teachers indicated that students applied what they learned.

$\underline{\text { Conclusions }}$

- It is more likely that teachers will teach the areas of agriscience that they are more knowledgeable about.

- Teachers teaching agriscience use a variety of teaching methods.

- Students apply what they learn in agriscience.

$\underline{\text { Summary and Conclusions of Agriscience Workshops/Classes Attended }}$

The West Virginia agricultural education teachers were asked how many agriscience classes/workshops they have attended since college graduation. About two-thirds of the teachers indicated that they had attended six or more agriscience classes or workshops. All had attended at least one agriscience class or workshop.

$\underline{\text { Conclusions }}$

Based on the information provided by West Virginia agricultural education teachers concerning the number of agriscience classes/workshops that they have attended, the following conclusion can be drawn:

- Teachers participate in workshops/classes offered on agriscience.

$\underline{\text { Summary and Conclusions of Level of Science Knowledge }}$

West Virginia agricultural education teachers were asked to rate their knowledge level on seven science topics. In all cases a score of $1=$ no knowledge, $2=$ heard and read about, but very 
little knowledge, 3 = took classes, possess some knowledge, and $4=$ applied, knowledgeable.

Teachers perceived themselves as having "heard and read about, but very little knowledge" about the topic of microbiology. Teachers reported that they had "took classes, possess some knowledge" on the topics of physics, geology, genetics, environmental science, and chemistry. Teachers perceived themselves as "applied, knowledgeable" about the topic of biology. A low relationship existed between years of experience and the topic of environmental science. Almost two-thirds of the teachers with less experience perceived themselves as having very little knowledge about the topic. A very strong relationship existed between highest degree held and the topic of microbiology. A little less than two-thirds of the teachers that held their bachelor's degree had very little knowledge about the topic.

\section{$\underline{\text { Conclusions }}$}

Based on the data provided by West Virginia agricultural education teachers on level of science knowledge, the following conclusion can be drawn:

- The majority of teachers perceive themselves as having scientific knowledge.

- It is more likely that teachers with more teaching experience are more knowledgeable about science.

- It is more likely that teachers with higher degrees are more knowledgeable about science.

\section{$\underline{\text { Summary and Conclusions of Science Classes/Workshops Attended }}$}

The West Virginia agricultural education teachers were asked how many science classes/workshops they have attended since college graduation. Almost half of the teachers had attended at least one science class or workshop. 


\section{$\underline{\text { Conclusions }}$}

Based on the information provided by West Virginia agricultural education teachers concerning the number of science classes/workshops that they have attended, the following conclusion can be drawn:

- West Virginia agricultural education teachers are involving themselves with science opportunities.

\section{$\underline{\text { Summary and Conclusion of Attitudes Toward Agriscience }}$}

The attitudes possessed by West Virginia agricultural education teachers of agriscience were divided into two sections. In the first section, teachers responded to seven agriscience issue questions. In the second section, teachers responded to ten statements that were preceded by "It is my job to...” In all cases a $1=$ strongly agree, $2=$ agree, $3=$ disagree, and $4=$ strongly disagree .

In the first section, teachers agreed with every agriscience statement with the exception of one. Teachers did not agree with the statement, "WV agriculture education programs should teach only agriscience courses."

In the second section of agriscience attitudes, teachers strongly agreed it was their job to teach high school students about agriscience, to involve students in agriscience related SAEs, and to develop instructional materials and lesson plans on agriscience. The teachers agreed it was their job to do all but one of the agriscience responsibilities. Teachers disagreed that it was their job to develop publications about agriscience. A moderate relationship existed between operating a farm and the responsibility of conducting agriscience research and developing publications about agriscience. Slightly more than half of the teachers that operated a farm agreed that it was their job to conduct agriscience research, but almost two-thirds did not agree that it was their job to develop publications about agriscience. 


\section{$\underline{\text { Conclusions }}$}

Based on the information provided by West Virginia agricultural education teachers on their attitudes toward agriscience, the following conclusions can be drawn:

- Teachers do not feel that agriscience courses should be the only courses taught in an agricultural education program.

- It is unlikely that teachers will develop publications about agriscience.

$\underline{\text { Summary and Conclusions of Implementation of Agriscience }}$

Information on how West Virginia agricultural education teachers implement agriscience was divided into two sections. In the first section, teachers rated nine barriers to teaching agriscience. In all cases a $1=$ not at all, $2=$ minor, $3=$ moderate, and $4=$ major. In the second section, teachers rated how they would prefer to receive agriscience. In all cases a $1=$ strongly agree, 2 = agree, 3 = disagree, and $4=$ strongly disagree .

In the first section, teachers rated all nine barriers to teaching agriscience as minor. Classroom/lab space, equipment, and instructional materials were considered the most serious minor barriers to teaching agriscience. Administration acceptance and community support were the least serious minor barriers to teaching agriscience. A low relationship existed between years of experience and the barrier of time. All of the teachers, with fifteen years of experience or more, indicated time as a major barrier to teaching agriscience.

In the second section, teachers strongly agreed that workshops were the preferred information source for agriscience. Teachers agreed that they would prefer to receive agriscience information from all of the information sources provided. 


\section{$\underline{\text { Conclusions }}$}

Based on the information provided by West Virginia agricultural education teachers on their attitudes toward agriscience, the following conclusions can be drawn:

- Teachers have overcome the barriers of teaching agriscience, but could still use assistance on equipment, classroom/lab space, and instructional materials.

- It is more likely that younger teachers will have more time to dedicate to overcoming the barriers and implementing agriscience.

\section{$\underline{\text { Recommendations }}$}

In order to inform secondary agricultural educators and to improve secondary agriculture programs in West Virginia, the following recommendations are made to the West Virginia University Agricultural and Environmental Education faculty and the West Virginia Department of Education Agricultural Education staff based on the results of this study:

- This study needs to be replicated in its complete or modified form to teachers nationwide or regionally to determine if the findings differ significantly from those in this study. A study on just biotechnology or agriscience could be conducted separately.

- Offer support to high school agricultural education departments to implement biotechnology and other scientifically enhanced curriculum.

- Offer competitive grants for programs that want to implement biotechnology or agriscience topics into their curriculum.

- Offer more biotechnology and agriscience classes and workshops for teachers.

- Offer incentives to agricultural education teachers for developing science enriched agriculture curriculum and for becoming certified to teach science. 
- Continue to pursue statewide science credit for agricultural education.

- Change undergraduate requirements of agricultural education majors by adding more science courses leading to a double certification in agricultural education and science. 


\section{REFERENCES}

Ary, D. Jacobs, L.C. \& Razavieh, A. (1996). Introduction to research in education. Orlando, FL: Harcourt Brace.

Dillman, D.A. (1978). Mail and telephone surveys. New York: John Wiley and Sons.

Dormody, T.J. (1993). Science credentialing and science credit in secondary school agricultural education. Journal of Agricultural Education 34 (2), 63-70

Haye, W. (1980, November). Should vo-ag become a science? The Agricultural Education Magazine 53 (5), 20.

Kirby, B.M. (1990, November). Attitudes, knowledge, and implementation of agricultural science by North Carolina agricultural education teachers. Proceedings From the Seventeenth Annual National Agricultural Education Research Meeting (pp. 71-79) Cincinnati, Ohio.

Hardy, R.W. (1985). Roles of Academe, Government, and Industry for Agriculture in a Changing World. Biotechnology in plant sciences, relevance to agriculture in the eighties. New York: Academic Press, 361-364.

Hillison, J. (1996). The origins of agriscience; or where did all that scientific agriculture come from? Journal of Agricultural Education_37 4), 8-13.

Pool, D.L. (1988, January). The agriculture teacher for the 1990s. The Agricultural Education Magazine 60 (7), 9-10.

Phipps, L.J. \& Osborne, E.W. (1988). Handbook on Agricultural Education in Public Schools. Danville, IL: Interstate. 
Martin, R.A. (1988, January). Infusing biotechnology into secondary agricultural programs. Proceedings of the Ag. Biotech > 88 International Conference and Exposition. Washington, DC.

Martin, R.A., Rajasekaran, B., Void, L. (1989). National study to determine the role of bioscience/biotechnology in the study of agriculture as perceived by vocational agriculture instructors. Proceedings from the Sixteenth Annual National Agricultural Education Research Meeting (pp. 243-250) Orlando, FL.

Miller, L.E. \& Smith, K. (1983). Handling nonreponse issues. Journal of Extension 21 (5), 11-13.

Moss, J.W. (1985). Science-related competencies taught in ornamental horticulture and introduction to agriculture. (Final Report). Raleigh, NC: North Carolina Department of Public Instruction.

National Research Council. (1988). Understanding agriculture: New directions for Education. Washington, DC.: National Academy Press.

National Council on Vocational Education. (1990). Occupational competencies; a study of the vocational-technical needs of the agribusiness and chemistry-based technology industries. Published report, Washington, DC.

Osborne, E. (1993, October). Rediscovering our niche. The Agricultural Education Magazine 66 (4), 3,12.

Smith, D, (1989, February). Toto, I don=t think we=re in Kansas Anymore. The Agricultural Education Magazine 61 (8), 8-11.

Sudman, S. \& Bradburn, N.M. (1982). Asking questions: A practical guide to questionnaire design. San Francisco, California: Josey Bass Publishers. 
Terry, R. (1993, October). Projecting an agriscience image. The Agricultural Education Magazine 66 (4), 9-10.

Vaughn, P. (1993, October). Teaching agriscience: A few cautions. The Agricultural Education Magazine 66 (4), 4. 
APPENDICES 


\section{APPENDICES A}

Initial Letter to West Virginia Agricultural Education Teachers 
Dear

We are conducting a thesis study to determine the knowledge level, teaching methods used, attitudes, and implementation of biotechnology and agriscience. We are gathering information from all agricultural education instructors in West Virginia. The results of this research could be used to impact college course offerings, teacher workshops and in-services, and agricultural education curriculum.

On the enclosed survey we have asked you to simply circle most of your responses. Although your participation is voluntary, we are asking you to please take a few minutes of your time to fill out the survey. Please answer every question that you feel comfortable answering. Please be assured that all information will be held completely confidential. You will notice a code number at the top right of the first page of the survey. This code will be used to facilitate the forwarding of additional mailings to you if necessary.

Enclosed with the questionnaire is a self-addressed stamped envelope for your convenience. If we might have your response by February 10, 2001, we would be most appreciative.

Thank you in advance for your cooperation.

Sincerely,

Jason E Hughes

Graduate Student

Agricultural Education
Dr. Stacy A. Gartin

Professor

Agricultural Education 


\section{APPENDICES B}

Follow-up Letter to West Virginia Agricultural Education Teachers 
February 21, 2001

Inside address

Dear

We recently mailed you a survey concerning the thesis study we are conducting to determine the knowledge level, teaching methods used, attitudes, and implementation of biotechnology and agriscience.

As of yet, we have not received your response. If you have responded let us thank you in advance. If not, please take a few minutes to fill out the enclosed survey. Your participation is voluntary, but your participation would be greatly appreciated.

On a personal note, I realize that you do not have a lot of extra time, especially to fill out surveys. I would just ask you to keep in mind that you would be helping me reach a goal of obtaining my Master's Degree this semester. Your assistance would be greatly appreciated.

Enclosed with the questionnaire is a self-addressed, return envelope for your convenience. If we might have your response by March 5, 2001, we would be most appreciative. Please feel free to fax the information to us at (304) 293-3752.

Thank you in advance for your cooperation.

Sincerely,

Jason E. Hughes

Graduate Student

Agricultural Education
Stacy A. Gartin

Professor

Agricultural Education 
APPENDICES C

Questionnaire 


\section{Attitudes, Knowledge, and Implementation of Biotechnology and Agriscience by West Virginia Agricultural Education Teachers Survey}

Please circle your level of knowledge and teaching method used in the following areas of biotechnology using the following scale: (Note: On the teaching method, please circle all that apply.)

\section{$\underline{\text { Topics }}$}

Level of Knowledge

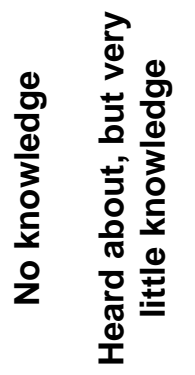

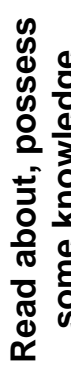

Teaching Method Used

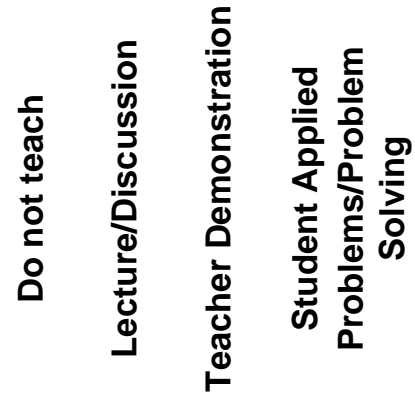

Recombinant DNA
Bioremediation
Gene Splicing
Genetic Engineering
Cloning
Transgenic species
Genetically modified food
Electrophoresis
Environmental Biotechnology
Food Biotechnology
Microbial Biotechnology
Hybridization
Plant Tissue Culture
Resistant plant species
Animal Reproduction
Growth Hormones (bST, pST)
Human Genomics
Biotechnology Ethics

1
1
1
1
1
1
1
1
1
1
1
1
1
1
1
1
1
1

$\begin{array}{lll}2 & 3 & 4 \\ 2 & 3 & 4 \\ 2 & 3 & 4 \\ 2 & 3 & 4 \\ 2 & 3 & 4 \\ 2 & 3 & 4 \\ 2 & 3 & 4 \\ 2 & 3 & 4 \\ 2 & 3 & 4 \\ 2 & 3 & 4 \\ 2 & 3 & 4 \\ 2 & 3 & 4 \\ 2 & 3 & 4 \\ 2 & 3 & 4 \\ 2 & 3 & 4 \\ 2 & 3 & 4 \\ 2 & 3 & 4 \\ 2 & 3 & 4\end{array}$

$\begin{array}{lllll}1 & 2 & 3 & 4 & 5 \\ 1 & 2 & 3 & 4 & 5 \\ 1 & 2 & 3 & 4 & 5 \\ 1 & 2 & 3 & 4 & 5 \\ 1 & 2 & 3 & 4 & 5 \\ 1 & 2 & 3 & 4 & 5 \\ 1 & 2 & 3 & 4 & 5 \\ 1 & 2 & 3 & 4 & 5 \\ 1 & 2 & 3 & 4 & 5 \\ 1 & 2 & 3 & 4 & 5 \\ 1 & 2 & 3 & 4 & 5 \\ 1 & 2 & 3 & 4 & 5 \\ 1 & 2 & 3 & 4 & 5 \\ 1 & 2 & 3 & 4 & 5 \\ 1 & 2 & 3 & 4 & 5 \\ 1 & 2 & 3 & 4 & 5 \\ 1 & 2 & 3 & 4 & 5 \\ 1 & 2 & 3 & 4 & 5\end{array}$

How many biotechnology classes/workshops have you attended? 


\section{Attitudes toward Biotechnology}

Please circle your response to the following statements using the following scale:

Cloning living organisms is morally wrong?

Cross breeding to produce hybrids is morally wrong? I support the use of biotechnology for human medicine? I support the genetic engineering of feed crops? I support the genetic engineering of food crops? I support the genetic engineering of animals? I support the use of biotechnology for environmental purposes? Biotechnology should be a class taught by AG-ED Teachers? Biotechnology should be a topic in an agriscience class? I believe that local, state, and federal money should be spent on teaching biotechnology?

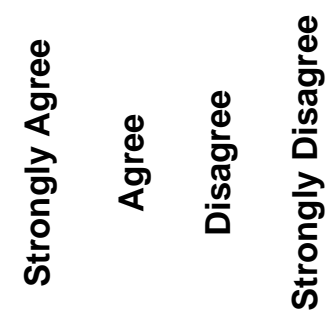

$\begin{array}{llll}1 & 2 & 3 & 4 \\ 1 & 2 & 3 & 4 \\ 1 & 2 & 3 & 4 \\ 1 & 2 & 3 & 4 \\ 1 & 2 & 3 & 4 \\ 1 & 2 & 3 & 4 \\ 1 & 2 & 3 & 4 \\ 1 & 2 & 3 & 4 \\ 1 & 2 & 3 & 4 \\ 1 & 2 & 3 & 4\end{array}$

Please circle your response to the following statements using the following scale:

\section{It is my job to...}

teach high school students about biotechnology develop instructional materials and lesson plans on biotechnology. educate farmers and agriculturists about biotechnology. educate public policy makers about biotechnology. develop publications about biotechnology. educate consumers about biotechnology. sponsor meetings related to biotechnology. conduct biotechnology research. distribute publications about biotechnology. involve students in biotechnology related SAEs.

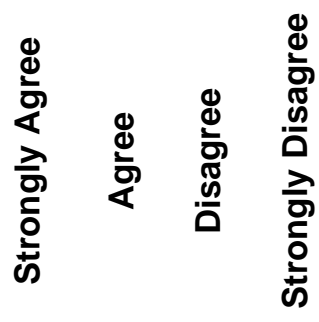

$\begin{array}{llll}1 & 2 & 3 & 4 \\ 1 & 2 & 3 & 4 \\ 1 & 2 & 3 & 4 \\ 1 & 2 & 3 & 4 \\ 1 & 2 & 3 & 4 \\ 1 & 2 & 3 & 4 \\ 1 & 2 & 3 & 4 \\ 1 & 2 & 3 & 4 \\ 1 & 2 & 3 & 4 \\ 1 & 2 & 3 & 4\end{array}$


Implementation of Biotechnology

Please rate how the following would be a barrier to you teaching biotechnology:

\section{Barrier}

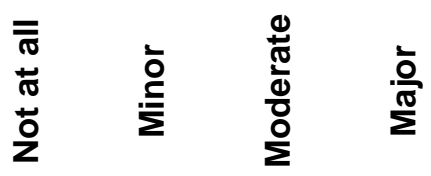

Equipment

Instructional Materials

Textbooks

Student Academic Ability

Teacher Knowledge

Time

Classroom/Lab Space

Community

Administration Acceptance

$\begin{array}{llll}1 & 2 & 3 & 4 \\ 1 & 2 & 3 & 4 \\ 1 & 2 & 3 & 4 \\ 1 & 2 & 3 & 4 \\ 1 & 2 & 3 & 4 \\ 1 & 2 & 3 & 4 \\ 1 & 2 & 3 & 4 \\ 1 & 2 & 3 & 4 \\ 1 & 2 & 3 & 4\end{array}$

Please circle your response to the following statements using the following scale:

I would prefer to receive biotechnology information from...

Internet

Workshops

Video Tapes

Slide sets/movies

University courses

Lesson Plans

Textbooks

Computer Programs

CD-Rom

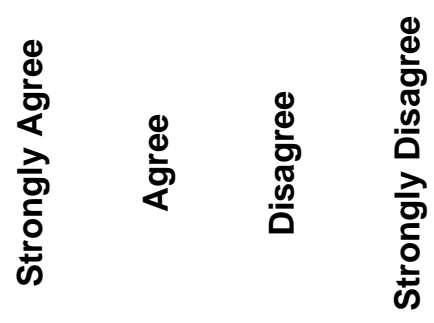

$\begin{array}{llll}1 & 2 & 3 & 4 \\ 1 & 2 & 3 & 4 \\ 1 & 2 & 3 & 4 \\ 1 & 2 & 3 & 4 \\ 1 & 2 & 3 & 4 \\ 1 & 2 & 3 & 4 \\ 1 & 2 & 3 & 4 \\ 1 & 2 & 3 & 4 \\ 1 & 2 & 3 & 4\end{array}$


Knowledge of Agriscience

Please circle your level of knowledge and teaching method used in the following areas of

Topics

Level of Knowledge

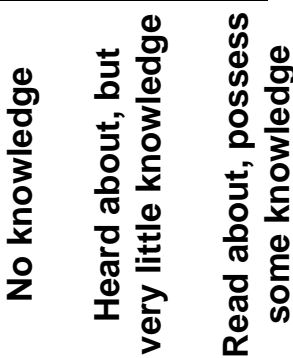

Teaching Method Used

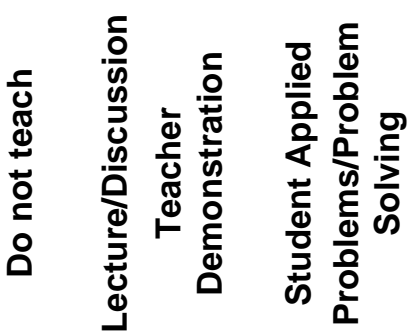

Soil Science

Botany/Plant Science

Hydroponics

Aquaculture

Animal and Vet Science

Forestry Science

Environmental Science

Ag. Engineering/Mechanics

Food Science

Plant Pathology

Horticulture

Crop Science

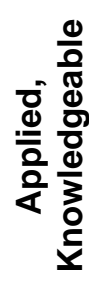

$\begin{array}{lllllllll}1 & 2 & 3 & 4 & 1 & 2 & 3 & 4 & 5 \\ 1 & 2 & 3 & 4 & 1 & 2 & 3 & 4 & 5 \\ 1 & 2 & 3 & 4 & 1 & 2 & 3 & 4 & 5 \\ 1 & 2 & 3 & 4 & 1 & 2 & 3 & 4 & 5 \\ 1 & 2 & 3 & 4 & 1 & 2 & 3 & 4 & 5 \\ 1 & 2 & 3 & 4 & 1 & 2 & 3 & 4 & 5 \\ 1 & 2 & 3 & 4 & 1 & 2 & 3 & 4 & 5 \\ 1 & 2 & 3 & 4 & 1 & 2 & 3 & 4 & 5 \\ 1 & 2 & 3 & 4 & 1 & 2 & 3 & 4 & 5 \\ 1 & 2 & 3 & 4 & 1 & 2 & 3 & 4 & 5 \\ 1 & 2 & 3 & 4 & 1 & 2 & 3 & 4 & 5 \\ 1 & 2 & 3 & 4 & 1 & 2 & 3 & 4 & 5\end{array}$

Please circle your level of knowledge in the following areas of science using the following scale:

Subject

Chemistry

Biology

Physics

Environmental Science

Microbiology

Genetics

Geology
Level of Knowledge

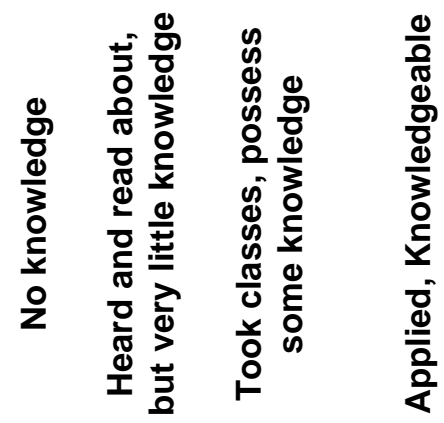


How many agriscience classes/workshops have you attended since college graduation?

How many science classes/workshops have you attended since college graduation?

\section{Attitudes toward Agriscience}

Please circle your response to the following statements using the following scale:

All WV ag. Programs should teach agriscience courses?

Agriscience should be taught at the middle school level?

WV ag. Programs should teach only agriscience courses?

WV agriscience courses should receive science credit?

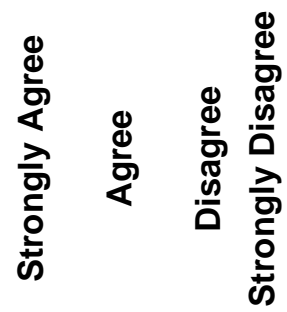

Agriscience courses are equally enriched with science concepts across WV?

$\mathrm{WV}$ ag. Teachers should be dual certified in science and AgEd?

WV ag. Teachers should have the option to be dual certified in science and $\mathrm{AgEd}$ ?

Please circle your rating of the following statements using the following scale:

It is my job to...

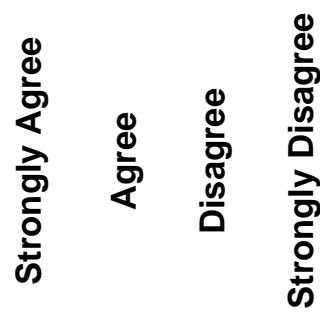

teach high school students about agriscience.

develop instructional materials and lesson plans on agriscience.

educate farmers and agriculturists about agriscience.

educate public policy makers about agriscience.

develop publications about agriscience.

educate consumers about agriscienece.

sponsor meetings related to agriscience.

conduct agriscience research.

distribute publications about agriscience.

involve students in agriscience related SAEs.

$\begin{array}{llll}1 & 2 & 3 & 4 \\ 1 & 2 & 3 & 4 \\ 1 & 2 & 3 & 4 \\ 1 & 2 & 3 & 4 \\ 1 & 2 & 3 & 4 \\ 1 & 2 & 3 & 4 \\ 1 & 2 & 3 & 4 \\ 1 & 2 & 3 & 4 \\ 1 & 2 & 3 & 4 \\ 1 & 2 & 3 & 4\end{array}$


Implementation of Agriscience

Please rate how the following would be a barrier to you teaching agriscience.

\section{Barrier}

Equipment

Instructional Materials

Textbooks

Student Academic Ability

Teacher Knowledge

Time

Classroom/Lab Space

Community

Administration Acceptance

\begin{tabular}{|c|c|c|}
\hline $\begin{array}{l}\overline{\bar{\pi}} \\
\bar{\pi} \\
\bar{\pi} \\
\mathbf{z}\end{array}$ & 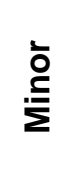 & $\begin{array}{l}\frac{\Phi}{\pi} \\
\frac{5}{d} \\
\frac{0}{0} \\
\frac{0}{\Sigma}\end{array}$ \\
\hline 1 & 2 & 3 \\
\hline 1 & 2 & 3 \\
\hline 1 & 2 & 3 \\
\hline 1 & 2 & 3 \\
\hline 1 & 2 & 3 \\
\hline 1 & 2 & 3 \\
\hline 1 & 2 & 3 \\
\hline 1 & 2 & 3 \\
\hline 1 & 2 & 3 \\
\hline
\end{tabular}

Please circle your response to the following statements using the following scale:

I would prefer to receive
agriscience information
from...
Internet
Workshops
Video Tapes
Slide sets/movies
University courses
Lesson Plans
Textbooks
Computer Programs
CD-Rom

\begin{tabular}{|c|c|c|}
\hline 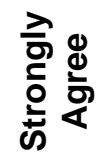 & $\begin{array}{l}\text { むँ } \\
\text { क্口 }\end{array}$ & 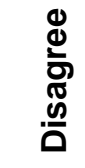 \\
\hline 1 & 2 & 3 \\
\hline 1 & 2 & 3 \\
\hline 1 & 2 & 3 \\
\hline 1 & 2 & 3 \\
\hline 1 & 2 & 3 \\
\hline 1 & 2 & 3 \\
\hline 1 & 2 & 3 \\
\hline 1 & 2 & 3 \\
\hline 1 & 2 & 3 \\
\hline
\end{tabular}

\section{Demographic Information}

1. How many years have you taught agricultural education, counting this year?

2. Circle your highest degree? BS MS PhD

3. Do you own or operate a farm? Yes No

4. Do you own or operate an agribusiness? Yes No

5. In the space provided, please list all of the agricultural education classes that you are teaching this school year and indicate if they are year long $(\mathrm{YL})$ or semester $(\mathrm{S})$. 
VITA

\section{Jason E. Hughes}

1992

Bachelor of Science

Agricultural Education

West Virginia University

Morgantown, WV

1992

Substitute Teacher

Grades 5-8 and 9-12

1993

Environmental Specialist

West Virginia Department of Agriculture

Pt. Pleasant, WV

1993

Agriscience Teacher

Wood County Technical Center

Parkersburg, WV

1996

Agriscience Teacher

St. Marys High School

St. Marys, WV

2001

Master of Science

Agricultural Education

West Virginia University

Morgantown, WV 